\title{
Diversity of echinostomes (Digenea: Echinostomatidae) in their snail hosts at high latitudes
}

\author{
Camila Pantoja ${ }^{1,2}$, Anna Faltýnková ${ }^{1 *}$ (D), Katie O’Dwyer ${ }^{3}$, Damien Jouet ${ }^{4}$, Karl Skírnisson ${ }^{5}$, and Olena Kudlai ${ }^{1,2}$ \\ ${ }^{1}$ Institute of Parasitology, Biology Centre of the Czech Academy of Sciences, Branišovská 31, 37005 České Budějovice, Czech Republic \\ 2 Institute of Ecology, Nature Research Centre, Akademijos 2, 08412 Vilnius, Lithuania \\ ${ }^{3}$ Marine and Freshwater Research Centre, Galway-Mayo Institute of Technology, H91 T8NW, Galway, Ireland \\ ${ }_{5}^{4}$ BioSpecT EA7506, Faculty of Pharmacy, University of Reims Champagne-Ardenne, 51 rue Cognacq-Jay, 51096 Reims Cedex, France \\ ${ }^{5}$ Laboratory of Parasitology, Institute for Experimental Pathology, Keldur, University of Iceland, IS-112 Reykjavík, Iceland
}

Received 26 April 2021, Accepted 24 June 2021, Published online 28 July 2021

\begin{abstract}
The biodiversity of freshwater ecosystems globally still leaves much to be discovered, not least in the trematode parasite fauna they support. Echinostome trematode parasites have complex, multiple-host life-cycles, often involving migratory bird definitive hosts, thus leading to widespread distributions. Here, we examined the echinostome diversity in freshwater ecosystems at high latitude locations in Iceland, Finland, Ireland and Alaska (USA). We report 14 echinostome species identified morphologically and molecularly from analyses of nadl and $28 \mathrm{~S}$ rDNA sequence data. We found echinostomes parasitising snails of 11 species from the families Lymnaeidae, Planorbidae, Physidae and Valvatidae. The number of echinostome species in different hosts did not vary greatly and ranged from one to three species. Of these 14 trematode species, we discovered four species (Echinoparyphium sp. 1, Echinoparyphium sp. 2, Neopetasiger sp. 5, and Echinostomatidae gen. sp.) as novel in Europe; we provide descriptions for the newly recorded species and those not previously associated with DNA sequences. Two species from Iceland (Neopetasiger islandicus and Echinoparyphium sp. 2) were recorded in both Iceland and North America. All species found in Ireland are new records for this country. Via an integrative taxonomic approach taken, both morphological and molecular data are provided for comparison with future studies to elucidate many of the unknown parasite life cycles and transmission routes. Our reports of species distributions spanning Europe and North America highlight the need for parasite biodiversity assessments across large geographical areas.
\end{abstract}

Key words: Trematoda, Morphology, Mitochondrial and nuclear DNA, Europe, North America, Mollusca.

Résumé - Diversité des Échinostomes (Digenea, Echinostomatidae) chez leurs hôtes mollusques aux latitudes élevées. La biodiversité des écosystèmes d'eau douce à l'échelle mondiale laisse encore beaucoup à découvrir, notamment dans la faune parasitaire des trématodes qu'ils abritent. Les parasites trématodes Échinostomes ont des cycles de vie complexes à hôtes multiples impliquant souvent des oiseaux migrateurs comme hôtes définitifs, conduisant ainsi à des distributions étendues. Ici, nous avons examiné la diversité des échinostomes dans les écosystèmes d'eau douce à des latitudes élevées en Islande, Finlande, Irlande et en Alaska (États-Unis). Nous rapportons 14 espèces d'échinostomes identifiées morphologiquement et moléculairement à partir d'analyses de données de séquences de nadl et d'ADNr 28S. Nous avons trouvé des échinostomes parasitant les mollusques de 11 espèces des familles Lymnaeidae, Planorbidae, Physidae et Valvatidae. Le nombre d'espèces d'échinostomes dans différents hôtes ne variait pas beaucoup et allait d'une à trois espèces. Sur ces 14 espèces de trématodes, nous avons découvert quatre espèces (Echinoparyphium sp. 1, Echinoparyphium sp. 2, Neopetasiger sp. 5, Echinostomatidae gen. sp.) comme nouvelles pour l'Europe; nous fournissons des descriptions pour les espèces nouvellement signalées et celles qui n'étaient pas précédemment associées à des séquences d'ADN. Deux espèces d'Islande (Neopetasiger islandicus et Echinoparyphium sp. 2) ont été signalées en Islande et en Amérique du Nord. Toutes les espèces trouvées en Irlande sont de nouveaux signalements pour ce pays. Grâce à une approche taxonomique intégrative, des données morphologiques et moléculaires sont fournies à des fins de comparaison avec des études futures afin d'élucider les nombreux cycles de vie et voies de transmission des parasites, qui sont inconnus. Nos données sur la répartition des espèces en Europe et en Amérique du Nord soulignent la nécessité d'évaluer la biodiversité des parasites dans de vastes zones géographiques.

\footnotetext{
*Corresponding author: faltyn. anna@gmail.com
} 


\section{Introduction}

In recent years, it has been increasingly uncovered that trematodes commonly complete their life-cycles in freshwaters in the sub-Arctic, using the short summer seasons, with many hosts available at high densities [8, 31, 36, 66, 78, 122]. Particularly Iceland, with its nesting bird populations using the fertile lakes, is an area of worldwide importance for birds [65] and therefore for the trematode parasites associated with them. The Arctic freshwater ecosystems, used by trematodes, are consistently under pressure because of climate change, possibly leading to further biodiversity loss due to latitudinal range shifts of organisms from boreal regions [18, 59, 64, 112, 139]. However, maintaining and exploring freshwater biodiversity is crucial for understanding how various species contribute to the functioning of freshwater ecosystems [44, 139], and parasites are a fundamental part of this diversity [1, 117]. Trematodes from the family Echinostomatidae are influential players in freshwater ecosystems [81]. They can affect the larval trematode component community species composition in snail populations $[83,87]$, they contribute substantially to energy flow in ecosystems [11], and they can cause diseases in humans and wildlife $[43,130]$. They are also considered effective competitors in combatting infection with schistosomes as the echinostome rediae actively feed on snail host tissue or other trematodes and can outcompete the less aggressive sporocysts [84]. Furthermore, a wide spectrum of first and second intermediate snail hosts to echinostomes has been revealed including multiple genera or even families of snails [24, 61, 84]. Because of this, echinostomes are frequently being used in ecological studies of host-parasite relationships [25], and they have been favoured in experimental model systems [39, 126].

The family Echinostomatidae Looss, 1899 is a fairly large group of trematodes with a cosmopolitan geographical distribution and with a remarkably diverse composition of genera (37 nominal genera recognised [126]), using a broad range of final vertebrate hosts (predominantly birds) [73]. Echinostomes, with a characteristic spined collar including a three-host lifecycle, have a wide range of second intermediate hosts (molluscs, other invertebrates, amphibians, and fishes) [69, 126]. Although they have received substantial attention from researchers and the family structure was recently re-evaluated based on the phylogenetic relationships of its members [126], their systematics are still non-satisfactory because of similar morphological characters between species, poor species diagnoses and convoluted synonymy [75]. There are several species complexes, particularly the "Echinostoma revolutum" group comprising species/lineages which have been defined as cryptic [24, 46, 48]. In recent years, in Europe and North America, but also in Africa, a substantial diversity of species of several genera was revealed via molecular genetic analyses; the species composition of the "revolutum" complex in Europe was partly solved, and new species representatives and species complexes (Ec. trivolvis and Ec. robustum) were recorded [24, 25, 32, 46, 48, 84, 118].

Particularly at the northern latitudes, including Iceland, Norway and northern Germany but also in Canada, new species were described and an unexpected diversity of echinostome trematodes was revealed in the associated freshwater ecosystems [51, 77, 118, 122], while in other regions (Alaska, Finland) data based only on morphology are available with molecular genetic data still lacking (see Table 1). These studies have pointed out the need for integrative taxonomy (with the preferred use of the mitochondrial gene $\operatorname{nad} 1$ as a marker) to further clarify a species status and to distinguish genetic lineages within species complexes [46]. Moreover, the first intermediate snail host species spectrum still remains to be explored as it turns out that with molecular data of both trematodes and snails different host spectra are revealed [78, 122].

Our primary aim was to investigate the diversity of the echinostome trematode fauna in snails in freshwater lakes in Iceland. Since this oceanic island lies on the East Atlantic Flyway, it is an important nesting place, with high densities of aquatic birds visiting annually [22, 65, 82]. The trematode species so far discovered there were found to be non-endemic to Iceland. The three echinostome species recently found in Iceland include Neopetasiger islandicus Kostadinova \& Skírnisson, 2007 afterwards also reported from North America [126], Echinostoma revolutum (Frölich, 1802) sensu stricto and Echinostoma sp. IG recorded from Europe [32, 46, 48]. Due to the apparent overlapping geographical distributions of echinostome species found in Iceland, we further included data from Ireland, Finland, and Alaska (USA) to investigate echinostome species diversity, host-use and distribution over a larger geographical area. We analysed novel DNA sequence data and associated them with morphological characterisations, together with data previously reported from Europe, North America, Africa, Asia and Australasia [24, 25, 46-48, 51, 84, 118, 122], with the aim of further contributing to the resolution of echinostome species diversity.

\section{Materials and methods}

\section{Collection of material}

A total of 6258 freshwater snails from Alaska, USA (May, June and July 2015), Finland (May-September 2007-2008), Iceland (June, July, August 2018-2019) and Ireland (July 2019) were collected for the present study (Table 2). The snails belonging to 11 species from the families Lymnaeidae, Planorbidae, Physidae and Valvatidae were collected in plastic containers with water from the locality and were brought to the laboratory. The snails were identified based on shell morphology using Burch [15] and Glöer [50]. In the laboratory, snails were placed into individual plastic cups filled with dechlorinated tap water and left for $24 \mathrm{~h}$ to detect natural emergence of cercariae. Emerged cercariae were examined live under a light microscope, Olympus BX51, BX41, photographed with the use of an attached digital camera and fixed in molecular grade ethanol for DNA isolation, and in $4 \%$ formalin solution for morphometric evaluation. Snails with emerging cercariae identified as belonging to the family Echinostomatidae were separated and the cercariae were subjected to subsequent molecular and morphological analyses. Thereafter, all snails were dissected under the dissecting stereomicroscope to detect all trematode intramolluscan stages (rediae). Vouchers of cercariae fixed in molecular grade ethanol and those fixed in formalin solution and transferred to $70 \%$ ethanol (see Table 3) 
Table 1. List of trematodes of the family Echinostomatidae recorded in freshwater in Iceland, Finland and Alaska, USA.

\begin{tabular}{|c|c|c|c|}
\hline Species & $\begin{array}{l}\text { Life-cycle } \\
\text { stage }\end{array}$ & Host* & Reference \\
\hline \multicolumn{4}{|l|}{ Iceland } \\
\hline \multirow{2}{*}{$\begin{array}{l}\text { Echinoparyphium recurvatum } \\
\text { (Linstow, 1873) }\end{array}$} & A & Melanitta nigra (L., 1758) & [14] \\
\hline & $\mathrm{C}$ & Radix peregra (O.F. Müller, 1774) & [7] \\
\hline \multirow{2}{*}{$\begin{array}{l}\text { Echinostoma revolutum (Fröhlich, } \\
\text { 1802) }\end{array}$} & A & Clangula hyemalis (L., 1758), Melanitta nigra (L., 1758) & {$[14]$} \\
\hline & $\mathrm{C}$ & Radix peregra (O.F. Müller, 1774) & [48] \\
\hline Echinostoma sp. IG & $\mathrm{C}$ & Radix peregra (O.F. Müller, 1774) & {$[48]$} \\
\hline $\begin{array}{l}\text { Hypoderaeum conoideum (Bloch, } \\
1782 \text { ) }\end{array}$ & M & Radix peregra (O.F. Müller, 1774) & [7] \\
\hline \multirow{2}{*}{$\begin{array}{l}\text { Neopetasiger islandicus } \\
\text { (Kostadinova \& Skírnisson, 2007) }\end{array}$} & A & Podiceps auritus (L., 1758) & [77] \\
\hline & $\mathrm{C}, \mathrm{M}$ & $\begin{array}{l}\text { Gyraulus cf. laevis (Alder, 1838), } \\
\text { Gasterosteus aculeatus L., } 1758\end{array}$ & [47] \\
\hline \multicolumn{4}{|c|}{ 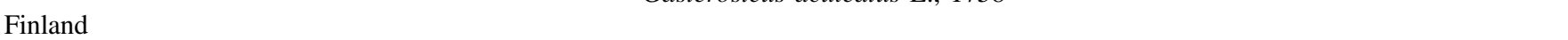 } \\
\hline $\begin{array}{l}\text { Echinoparyphium aconiatum } \\
\text { Dietz, } 1909\end{array}$ & $\mathrm{C}$ & Lymnaea stagnalis (L., 1758) & {$[76,101,132]$} \\
\hline \multirow[t]{2}{*}{$\begin{array}{l}\text { Echinoparyphium recurvatum } \\
\text { (Linstow, 1873) }\end{array}$} & A & $\begin{array}{l}\text { Anas acuta } \mathrm{L} ., 1758, \text { A. crecca } \mathrm{L} ., 1758, \\
\quad \text { A. platyrhynchos L., 1758, Aythia fuligula (L., 1758) }\end{array}$ & [13] \\
\hline & $\mathrm{C}$ & Lymnaea peregra (O.F. Müller, 1774) & {$[76,101,132]$} \\
\hline Echinoparyphium sp. 1 & $\mathrm{C}$ & Valvata macrostoma Mörch, 1864 & [37] \\
\hline Echinoparyphium sp. 2 & $\mathrm{C}$ & Valvata macrostoma Mörch, 1864 & [37] \\
\hline \multirow[t]{2}{*}{$\begin{array}{l}\text { Echinostoma revolutum } \\
\text { (Fröhlich, 1802) }\end{array}$} & A & $\begin{array}{l}\text { Anas acuta L., 1758, A. clypeata L., } 1758, \\
\text { A. crecca L., } 1758, \text { A. penelope L., } 1758 \text {, A. platyrhynchos L., } \\
\text { 1758, A. querquedula L., 1758, Aythya ferina (L., 1758), } \\
\text { Ay. fuligula (L., 1758) }\end{array}$ & [13] \\
\hline & $\mathrm{C}$ & L. stagnalis (L., 1758), L. peregra (O.F. Müller, 1774) & {$[101,132,138]$} \\
\hline \multirow[t]{2}{*}{$\begin{array}{l}\text { Hypoderaeum conoideum } \\
\text { (Bloch, 1782) }\end{array}$} & A & $\begin{array}{l}\text { Anas acuta } \mathrm{L} ., 1758, \text { A. crecca L., } 1758 \\
\text { A. platyrhynchos L., } 1758\end{array}$ & [13] \\
\hline & $\mathrm{C}$ & L. stagnalis (L., 1758) & {$[101,132,138]$} \\
\hline \multicolumn{4}{|l|}{ Alaska, USA } \\
\hline $\begin{array}{l}\text { Echinoparyphium aconiatum } \\
\text { Dietz, } 1909\end{array}$ & A & Limnodromus scolopaceus (Say, 1823) & {$[10]$} \\
\hline $\begin{array}{l}\text { Echinoparyphium recurvatum } \\
\text { (Linstow, 1873) }\end{array}$ & A & $\begin{array}{l}\text { Larus hyperboreus Gunnerus, 1767, Limosa laponica (L., 1758), } \\
\quad \text { Pluvialis squatarola (L., 1758) }\end{array}$ & {$[10,16]$} \\
\hline $\begin{array}{l}\text { Echinostoma calawayensis Barker } \\
\& \text { Noll, } 1915\end{array}$ & A & Ondatra zibethicus (Linnaeus, 1766) & {$[70]$} \\
\hline Echinostoma trivolvis (Cort, 1914) & A & Calidris alpina (L., 1758) & [17] \\
\hline
\end{tabular}

* Original names of hosts were used.

are kept in the Helminthological collection of the Institute of Parasitology (IPCAS), Biology Centre of the Czech Academy of Sciences, České Budějovice, Czech Republic.

\section{DNA extraction, amplification, and sequencing}

About 20-25 cercariae per sample were used for DNA extractions, following the protocol described by Georgieva et al. [48] (Table 3). Initially, to delineate and identify our isolates, we sequenced the section of the mitochondrial gene nicotinamide adenine dinucleotide dehydrogenase subunit 1 (nad1), following previous studies for echinostomes [24, 46, $48,51,84]$. Thereafter, we sequenced the $28 S$ section of one or two isolates representing different species in our samples to compare them to species for which nad 1 sequences were not available and identify the position of several species within the family Echinostomatidae. The section of the nad 1 gene was amplified using the primers NDJ11 and NDJ2A [76, 97], following PCR conditions as described by Laidemitt et al. [84]. The section of the nuclear $28 S$ rRNA gene (28S) was amplified using primers digl2 and 1500R [121], following PCR conditions as described by Tkach et al. [126]. The amplified DNA was purified using exonuclease I and shrimp alkaline phosphatase enzymes [136] and sequenced using PCR primers and internal primers ECD2 and 300F [88, 89] for the $28 S$ section. Cycle sequencing of DNA was carried out applying ABI Big Dye ${ }^{\mathrm{TM}}$ v.3.1 chemistry at the commercial company SEQme (Dobřřš, Czech Republic, https://www. seqme.eu) with the use of an AB3730x1 capillary sequencer. Sequences were assembled and edited using Geneious v. 11 (Biomatters, Auckland, New Zealand) and deposited in GenBank. 
Table 2. Summary data on localities and snail species examined and infected with echinostomes.

\begin{tabular}{|c|c|c|c|c|c|}
\hline Locality & Coordinates & Snail species & $\begin{array}{c}\text { Sample } \\
\text { size }\end{array}$ & $\begin{array}{c}\text { No. } \\
\text { infected }\end{array}$ & $\begin{array}{c}\text { Prevalence } \\
(\%)\end{array}$ \\
\hline \multicolumn{6}{|l|}{ Iceland } \\
\hline Pond in Family Park, Reykjavík & $64^{\circ} 08^{\prime} 14.5^{\prime \prime} \mathrm{N}, 21^{\circ} 52^{\prime} 02.6^{\prime \prime} \mathrm{W}$ & Radix balthica & 352 & 4 & 1.1 \\
\hline \multirow{2}{*}{$\begin{array}{l}\text { Pond at Nordic House, Vatnsmýri } \\
\text { Nature Reserve, Reykjavík }\end{array}$} & $64^{\circ} 08^{\prime} 19^{\prime \prime} \mathrm{N}, 21^{\circ} 56^{\prime} 45^{\prime \prime} \mathrm{W}$ & Radix balthica & 687 & 177 & 25.8 \\
\hline & & Physa acuta & 699 & 132 & 18.9 \\
\hline Lake Rauðavatn (near Reykjavík) & $64^{\circ} 06^{\prime} 22.9^{\prime \prime} \mathrm{N}, 21^{\circ} 46^{\prime} 34.4^{\prime \prime} \mathrm{W}$ & Radix balthica & 712 & 21 & 2.9 \\
\hline \multirow[t]{2}{*}{ Lake Mývatn, Helgavogur } & $65^{\circ} 38^{\prime} 05.8^{\prime \prime} \mathrm{N}, 16^{\circ} 55^{\prime} 30.4^{\prime \prime} \mathrm{W}$ & Radix balthica & 265 & 50 & 18.9 \\
\hline & & Gyraulus cf. parvus & 212 & 13 & 6.1 \\
\hline \multirow{2}{*}{ Lake Ashildarholtsvatn } & $65^{\circ} 44^{\prime} 00.6^{\prime \prime} \mathrm{N}, 19^{\circ} 37^{\prime} 23.8^{\prime \prime} \mathrm{W}$ & Radix balthica & 244 & 24 & 9.8 \\
\hline & & Gyraulus cf. parvus & 206 & 9 & 4.4 \\
\hline \multicolumn{6}{|l|}{ Ireland } \\
\hline \multirow[t]{5}{*}{ Lough Corrib } & $53^{\circ} 21^{\prime} 27.0^{\prime \prime} \mathrm{N}, 9^{\circ} 04^{\prime} 36.0^{\prime \prime} \mathrm{W}$ & Radix balthica & 573 & 10 & 1.7 \\
\hline & & Lymnaea stagnalis & 132 & 2 & 1.5 \\
\hline & & Myxas glutinosa & 60 & 1 & 1.7 \\
\hline & & $\begin{array}{l}\text { Planorbarius } \\
\text { corneus }\end{array}$ & 182 & 2 & 1.1 \\
\hline & & Planorbis planorbis & 32 & 2 & 6.3 \\
\hline Killeeneen & $53^{\circ} 13^{\prime} 30.0^{\prime \prime} \mathrm{N}, 8^{\circ} 47^{\prime} 43.0^{\prime \prime} \mathrm{W}$ & Lymnaea stagnalis & 10 & 1 & 10 \\
\hline Hackett Lough & $53^{\circ} 29^{\prime} 27.0^{\prime \prime} \mathrm{N} 9^{\circ} 02^{\prime} 31.0^{\prime \prime} \mathrm{W}$ & Lymnaea stagnalis & 39 & 1 & 2.6 \\
\hline \multirow{2}{*}{ Lough Mask } & $53^{\circ} 37^{\prime} 41.0^{\prime \prime} \mathrm{N}, 9^{\circ} 17^{\prime} 01.0^{\prime \prime} \mathrm{W}$ & Radix balthica & 104 & 2 & 1.9 \\
\hline & & Stagnicola fuscus & 38 & 1 & 2.6 \\
\hline \multicolumn{6}{|l|}{ Alaska, USA } \\
\hline Tanana, pool on river bank & $64^{\circ} 15^{\prime} 26.4^{\prime \prime} \mathrm{N}, 146^{\circ} 09^{\prime} 46.6^{\prime \prime} \mathrm{W}$ & Stagnicola elodes & 201 & 3 & 1.5 \\
\hline Fairbanks, small lake near airport & $64^{\circ} 47^{\prime} 56.7^{\prime \prime} \mathrm{N}, 147^{\circ} 51^{\prime} 43.6^{\prime \prime} \mathrm{W}$ & Radix auricularia & 1 & 1 & 100 \\
\hline \multicolumn{6}{|l|}{ Finland } \\
\hline \multirow[t]{3}{*}{ Lake Konnevesi } & $62^{\circ} 37^{\prime} 00.4^{\prime \prime} \mathrm{N}, 26^{\circ} 20^{\prime} 57.9^{\prime \prime} \mathrm{E}$ & Valvata macrostoma & 1447 & 60 & 4.1 \\
\hline & & Myxas glutinosa & 18 & 1 & 5.6 \\
\hline & & Radix balthica & 27 & 1 & 3.7 \\
\hline Huumonjärvi & $65^{\circ} 06^{\prime} 06.5^{\prime \prime} \mathrm{N}, 26^{\circ} 08^{\prime} 13.3^{\prime \prime} \mathrm{E}$ & Lymnaea stagnalis & 17 & 9 & 52.9 \\
\hline
\end{tabular}

To confirm the morphology-based identification of snail species, the partial mitochondrial cytochrome $c$ oxidase subunit 1 (cox 1$)$ gene and the internal transcribed spacer 2 (ITS2) sequences were generated for ten isolates (Table 3 ). The extraction protocol used was the same as for cercarial isolates (see above). The section of the cox 1 gene was amplified using the primers LCO1490 and HC02198 and the protocol described by Folmer et al. [38] and the ITS 2 region was amplified using the primer pair RadITS2 and RADITS2RIXOR and the protocol described by Soldánová et al. [122].

\section{Phylogenetic analyses}

Four alignments including novel and previously published sequences for echinostomes were built using MUSCLE [29] implemented in Geneious v. 11. Alignment 1 (431 nucleotides (nt)) included novel nad1 sequences of Echinoparyphium spp. $(n=25)$ and sequences of this genus available in GenBank $(n=31)$. The sequence of Echinostoma revolutum (KC618451) was used as the outgroup. Alignment 2 (417 nt) included nad 1 sequences of Echinostoma spp. generated in this study $(n=13)$ and retrieved from GenBank $(n=27)$. The sequence of Patagifer sp. (MK534424) was used as the outgroup. Alignment 3 (402 nt) included nad 1 sequences of Neopetasiger spp. generated in this study $(n=4)$ and retrieved from GenBank $(n=10)$. The sequence of Drepanocephalus auritus (KP053262) was used as the outgroup. The nad 1 sequences were aligned with reference to the amino acid translation, using the trematode mitochondrial code (translation table 21) [42, 105]. Alignment 4 (1137 nt) included $28 S$ sequences obtained during the present study $(n=19)$ and sequences of other representatives of the family Echinostomatidae available in GenBank $(n=36)$. The sequence of Caballerotrema sp. (KT956941) was used as the outgroup. Taxa used as the outgroups were selected based on the results of the phylogenetic analyses of the Echinostomatoidea and Echinostoma published by Tkach et al. [126] and Georgieva et al. [46, 48].

Bayesian inference (BI) and maximum likelihood (ML) phylogenetic analyses were conducted using MrBayes version 3.2.3. [113] and PhyML version 3.0 [56] software, respectively. Prior to analyses, the best-fitting model was estimated with jModelTest 2.1.2 [23]. The general time-reversible model incorporating invariant sites and gamma distributed among-site rate variations $(\mathrm{GTR}+\mathrm{I}+\mathrm{G})$ was selected for all datasets. Markov Chain Monte Carlo (MCMC) chains were run for 10,000,000 (Alignments 1, 2 and 4) or 3,000,000 (Alignment 3) generations, log-likelihood scores were plotted and only the final $75 \%$ of trees were used in BI analysis to produce the consensus trees. Nodal support for the ML analysis of all four alignments was estimated by performing 100 bootstrap pseudoreplicates. Trees were visualised using FigTree ver. 1.4 software [110]. Pairwise genetic distances were calculated using the p-distance 
Table 3. Summary data for the echinostomes and snail isolates used for generation of the nad1, cox $1,28 S$ and ITS2 sequences in the present study.

\begin{tabular}{|c|c|c|c|c|c|c|}
\hline \multirow[t]{2}{*}{ Species } & \multirow[t]{2}{*}{ Isolate } & \multirow[t]{2}{*}{ Host species } & \multirow[t]{2}{*}{ Locality } & \multicolumn{2}{|c|}{ GenBank ID } & \multirow[t]{2}{*}{ IPCAS No } \\
\hline & & & & $\operatorname{nad} 1 / \operatorname{cox} 1^{\text {a }}$ & $28 S / I T S 2^{\mathrm{b}}$ & \\
\hline Echinoparyphium aconiatum & AF227 & Lymnaea stagnalis & Ireland & MZ404641 & MZ409801 & $\mathrm{D}-825 / \mathrm{E}^{\mathrm{c}}$ \\
\hline Echinoparyphium aconiatum & AF 225 & Lymnaea stagnalis & Ireland & MZ404642 & - & - \\
\hline Echinoparyphium aconiatum & AF226 & Lymnaea stagnalis & Ireland & MZ404643 & - & - \\
\hline Echinoparyphium aconiatum & AF274 & Lymnaea stagnalis & Finland & MZ404644 & - & - \\
\hline Echinoparyphium aconiatum & AF275 & Lymnaea stagnalis & Finland & MZ404645 & - & - \\
\hline Echinoparyphium aconiatum & AF273 & Lymnaea stagnalis & Finland & MZ404646 & MZ409802 & - \\
\hline Echinoparyphium recurvatum & AF210 & Radix balthica & Iceland & MZ404647 & - & - \\
\hline Echinoparyphium recurvatum & AF211 & Radix balthica & Iceland & MZ404648 & - & D-196/E \\
\hline Echinoparyphium recurvatum & AF228 & Radix balthica & Iceland & MZ404649 & - & - \\
\hline Echinoparyphium recurvatum & AF256 & Radix balthica & Finland & MZ404650 & - & - \\
\hline Echinoparyphium recurvatum & AF229 & Radix balthica & Ireland & MZ404651 & - & - \\
\hline Echinoparyphium recurvatum & AF222 & Radix balthica & Ireland & MZ404652 & - & - \\
\hline Echinoparyphium recurvatum & AF205 & Radix balthica & Iceland & MZ404653 & - & - \\
\hline Echinoparyphium recurvatum & AF220 & Radix balthica & Iceland & MZ404654 & - & D-196/F \\
\hline Echinoparyphium recurvatum & $\mathrm{AF} 254$ & Myxas glutinosa & Finland & MZ404655 & MZ409803 & - \\
\hline Echinoparyphium recurvatum & $\mathrm{AF} 255$ & Myxas glutinosa & Finland & MZ404656 & - & - \\
\hline Echinoparyphium recurvatum & AF204 & Radix balthica & Iceland & MZ404657 & MZ409804 & \\
\hline Echinoparyphium rubrum & AF241 & Stagnicola elodes & Alaska & MZ404658 & MZ409805 & D-833/E \\
\hline Echinoparyphium rubrum & AF244 & Stagnicola elodes & Alaska & MZ404659 & MZ409806 & D-833/F \\
\hline Echinoparyphium sp. 1 & AF 251 & Valvata macrostoma & Finland & MZ404660 & - & D-834/E \\
\hline Echinoparyphium sp. 1 & AF252 & Valvata macrostoma & Finland & MZ404661 & MZ409807 & - \\
\hline Echinoparyphium sp. 1 & AF253 & Valvata macrostoma & Finland & MZ404662 & - & D-834/F \\
\hline Echinoparyphium sp. 2 & AF421 & Physa acuta & Iceland & MZ404663 & - & D-835/E \\
\hline Echinoparyphium sp. 2 & AF420 & Physa acuta & Iceland & MZ404664 & MZ409808 & - \\
\hline Echinoparyphium sp. 2 & AF423 & Physa acuta & Iceland & MZ404665 & - & $\mathrm{D}-835 / \mathrm{F}$ \\
\hline Echinostoma nasincovae & AF232 & $\begin{array}{c}\text { Planorbarius } \\
\text { corneus }\end{array}$ & Ireland & MZ404666 & MZ409809 & D-289/E \\
\hline Echinostoma revolutum s. str. & AF206 & Radix balthica & Iceland & MZ404667 & MZ409810 & D-130/E \\
\hline Echinostoma revolutum s. str. & AF214 & Radix balthica & Iceland & MZ404668 & - & - \\
\hline Echinostoma revolutum s. str. & AF219 & Radix balthica & Iceland & MZ404669 & - & - \\
\hline Echinostoma revolutum s. str. & AF 215 & Radix balthica & Iceland & MZ404670 & - & - \\
\hline Echinostoma revolutum s. str. & AF216 & Radix balthica & Iceland & MZ404671 & - & - \\
\hline Echinostoma revolutum s. str. & AF217 & Radix balthica & Iceland & MZ404672 & - & - \\
\hline Echinostoma revolutum & AF235 & Radix auricularia & Alaska & MZ404673 & MZ409811 & D-836/E/F \\
\hline Echinostoma revolutum & AF236 & Stagnicola elodes & Alaska & MZ404674 & - & - \\
\hline Echinostoma revolutum & AF237 & Stagnicola elodes & Alaska & MZ404675 & - & - \\
\hline Echinostoma sp. IG & AF218 & Radix balthica & Iceland & MZ404676 & MZ409812 & - \\
\hline Echinostoma sp. IG & AF221 & Radix balthica & Iceland & MZ404677 & - & $\mathrm{D}-837 / \mathrm{E}$ \\
\hline Echinostoma sp. IG & AF231 & Myxas glutinosa & Ireland & MZ404678 & MZ409813 & - \\
\hline Hypoderaeum conoideum & AF261 & Lymnaea stagnalis & Finland & MZ404679 & MZ409814 & - \\
\hline Hypoderaeum conoideum & AF262 & Lymnaea stagnalis & Finland & MZ404680 & - & - \\
\hline Hypoderaeum conoideum & AF257 & Lymnaea stagnalis & Finland & MZ404681 & - & - \\
\hline Hypoderaeum conoideum & AF259 & Lymnaea stagnalis & Finland & MZ404682 & - & D-138/E \\
\hline Moliniella anceps & AF230 & Stagnicola fuscus & Ireland & MZ404683 & MZ409815 & D-176/E \\
\hline Neopetasiger islandicus & AF416 & Gyraulus cf. parvus & Iceland & MZ404684 & - & - \\
\hline Neopetasiger islandicus & AF418 & Gyraulus cf. parvus & Iceland & MZ404685 & - & - \\
\hline Neopetasiger islandicus & AF415 & Gyraulus cf. parvus & Iceland & MZ404686 & MZ409816 & D-720/E \\
\hline Neopetasiger sp. 5 & AF233 & Planorbis planorbis & Ireland & MZ404687 & MZ409817 & D-838/E \\
\hline Echinostomatidae gen. sp. & AF258 & Lymnaea stagnalis & Finland & MZ404688 & MZ409818 & - \\
\hline Echinostomatidae gen. sp. & AF260 & Lymnaea stagnalis & Finland & MZ404689 & MZ409819 & $\mathrm{D}-839 / \mathrm{E} / \mathrm{F}$ \\
\hline Gyraulus cf. parvus & AF351 & - & Iceland & - & MZ400492 ${ }^{\mathrm{b}}$ & - \\
\hline Gyraulus cf. parvus & AF352 & - & Iceland & MZ398103 $^{\mathrm{a}}$ & MZ400494 ${ }^{\mathrm{b}}$ & - \\
\hline Gyraulus cf. parvus & AF354 & - & Iceland & MZ398105 & MZ400495 & - \\
\hline Gyraulus cf. parvus & AF355 & - & Iceland & - & MZ400491 ${ }^{\mathrm{b}}$ & - \\
\hline Myxas glutinosa & AF338 & - & Ireland & MZ396110 & MZ400489 & - \\
\hline Physa acuta & AF344 & - & Iceland & MZ396244 ${ }^{\mathrm{a}}$ & MZ400493 & - \\
\hline Radix balthica & AF347 & - & Iceland & - & MZ400490 & - \\
\hline Radix balthica & AF348 & - & Iceland & - & MZ400497 & - \\
\hline
\end{tabular}


Table 3. (Continued)

\begin{tabular}{|c|c|c|c|c|c|c|}
\hline \multirow[t]{2}{*}{ Species } & \multirow[t]{2}{*}{ Isolate } & \multirow[t]{2}{*}{ Host species } & \multirow[t]{2}{*}{ Locality } & \multicolumn{2}{|c|}{ GenBank ID } & \multirow[t]{2}{*}{ IPCAS No } \\
\hline & & & & $\operatorname{nad} 1 / \operatorname{cox} 1^{\mathrm{a}}$ & $28 S / I T S 2^{b}$ & \\
\hline Radix balthica & AF349 & - & Iceland & - & MZ400496 & - \\
\hline Radix balthica & AF353 & - & Iceland & - & $\mathrm{MZ400505^{ \textrm {b } }}$ & - \\
\hline
\end{tabular}

${ }^{a}$ Sequence for $\operatorname{cox} 1$;

${ }^{\mathrm{b}}$ sequence for ITS2;

${ }^{c}$ Abbreviations: E - molecular grade ethanol; F - fixed in formalin and transferred to $70 \%$ ethanol.

model in MEGA ver. X [80]. New sequences of echinostomes were deposited in GenBank with accession numbers MZ404641-MZ404689 and MZ409801-MZ409819.

\section{Morphological evaluation}

Cercariae and rediae were examined live under the light microscope Olympus BX51 and BX41 for primary identification based on their morphology, following the keys of Faltýnková et al. [34, 35]. Series of photomicrographs of live individuals and formalin fixed samples were taken with a digital camera on Olympus BX51 and BX41 microscopes; in locations with microscopes with no camera (Alaska, Finland), hand drawings of live cercariae were made. Measurements for each isolate were taken from the digital images with the aid of QuickPHOTO CAMERA 2.3 image analysis software. Metrical data in the descriptions are based on live specimens and fixed material (formalin and/or ethanol). All measurements in the descriptions are in micrometres and are presented as the range, followed by the mean in parentheses. Measurements of fixed material are provided separately.

\section{Results}

In total, 14 echinostome species were identified infecting snails from four different families: Lymnaeidae, Planorbidae, Physidae and Valvatidae, sampled in Alaska, Iceland, Finland and Ireland.

\section{DNA-based identification}

During the present study, 68 novel sequences, including 19 of $28 S \mathrm{rDNA}$ and 49 of $n a d 1$ were generated for 49 cercarial isolates belonging to the family Echinostomatidae (Table 3). Molecular delineation of the isolates and their species identification was performed based on the analysis of nad 1 sequence data via comparison to previously published data for echinostomes (Table 4). Analyses of the $28 S \mathrm{rDNA}$ sequence data were conducted to explore relationships among collected taxa and to identify several species for which nad 1 sequences were not available in GenBank. Cercariae of Echinoparyphium rubrum (Cort, 1917) and Moliniella anceps (Molin, 1859) were molecularly identified based on the $28 S$ sequence data analyses. For Echinostoma revolutum we follow the concept of Georgieva et al. [46] and use Ec. revolutum sensu stricto (s. str.) for European isolates and Ec. revolutum of Detwiler et al. [24] for North American isolates. An unknown species of Neopetasiger obtained in the present study was named using the subsequent number following the study of Selbach et al. [118]. Pairwise genetic distances of the highlighted clades (see Figs. 1-4) are presented in the Supplementary Tables S1, S2, S3 and S4.

The newly generated nad 1 sequences for isolates of Echinoparyphium spp. clustered in five strongly supported clades (Fig. 1) in the tree resulting from BI and ML analyses of the first alignment: five isolates collected from Radix balthica (Linnaeus) in Iceland, three isolates from $R$. balthica in Ireland and three isolates from R. balthica and M. glutinosa (O.F. Müller) in Finland clustered with isolates of E. recurvatum (Linstow, 1873) previously reported in Europe [76, 122]; two isolates collected from Stagnicola elodes (Say) in Alaska which were identified as E. rubrum clustered with five isolates of unidentified species of Echinoparyphium (five species) and one isolate of unidentified species of Hypoderaeum reported in Canada [51]; three isolates collected from Physa acuta Draparnaud in Iceland, to which we refer as Echinoparyphium sp. 2, clustered with two isolates of unidentified species of Echinoparyphium and one isolate of unidentified species of Hypoderaeum reported in Canada [51]; three isolates collected from Valvata macrostoma Mörch in Finland, to which we refer as Echinoparyphium sp. 1, formed a separate clade to other Echinoparyphium spp.; and three isolates from Lymnaea stagnalis (Linnaeus) collected in Ireland and three isolates from L. stagnalis in Finland clustered with an isolate of E. aconiatum Dietz, 1909 previously reported in Europe [76]. The sequence divergence between isolates in clade "E. aconiatum" was $0-1.4 \%(0-5 \mathrm{nt})$, between isolates in clade "E. recurvatum" it was $0-3.4 \%(0-12 \mathrm{nt})$, between isolates in clade " $E$. rubrum" it was $0-1.9 \%(0-8 \mathrm{nt})$, and between isolates in clade "Echinoparyphium sp. 2" it was 0-2.4\% (0-8 nt) (Alignment 1; $417 \mathrm{nt})$. Sequences of Echinoparyphium sp. 1 were identical.

The phylogenetic tree resulting from BI and ML analyses of the data in the second alignment showed that newly generated nad 1 sequences of isolates of Echinostoma spp. clustered within four strongly supported clades corresponding to four species (Fig. 2): six isolates collected from R. balthica in Iceland clustered with isolates of Ec. revolutum (Frölich, 1802) s. str. previously reported in Europe including Iceland [46, 48]; three isolates collected from Radix auricularia (Linnaeus) and $S$. elodes in Alaska clustered with Ec. revolutum previously reported in the USA [24, 25] and Ec. trivolvis Lineage A reported from Canada [51]; one isolate collected from Planorbarius corneus (Linnaeus) in Ireland clustered with the species Echinostoma nasincovae Faltýnková, Georgieva, 
Table 4. List of trematodes of the superfamily Echinostomatoidea used in the phylogenetic analyses.

\begin{tabular}{|c|c|c|c|c|c|}
\hline Species & Host species* & Locality & $\begin{array}{l}\text { GenBank } \\
\text { ID, nad } 1\end{array}$ & $\begin{array}{c}\text { GenBank } \\
\text { ID, } 28 S\end{array}$ & Reference \\
\hline Artyfechinostomum sufrartyfex & Sus scrofa domestica & India & - & KF781303 & $\begin{array}{l}\text { Tandon et al. } \\
\text { (unpublished) }\end{array}$ \\
\hline Caballerotrema sp. & Arapaima gigas & Peru & - & KT956941 & [126] \\
\hline Chaunocephalus ferox & Ciconia nigra & Ukraine & - & KT447522 & {$[55]$} \\
\hline Drepanocephalus auritus & Planorbella trivolvis & USA & KP053262 & - & [108] \\
\hline Echinoparyphium aconiatum & Lymnaea stagnalis & Finland & AY168947 & - & {$[76]$} \\
\hline Echinoparyphium aconiatum & Lymnaea stagnalis & Czech Republic & - & KT956912 & {$[126]$} \\
\hline Echinoparyphium cinctum & Anas platyrhynchos & Ukraine & - & AF184260 & {$[128]$} \\
\hline Echinoparyphium ellisi & Anas platyrhynchos & New Zealand & KY436406 & - & {$[45]$} \\
\hline Echinoparyphium ellisi & Anas platyrhynchos & New Zealand & - & KY436410 & {$[45]$} \\
\hline Echinoparyphium hydromyos & Hydromys chrysogaster & Australia & AF026290 & - & [97] \\
\hline Echinoparyphium mordwikoi & Valvata piscinalis & Lithuania & - & KJ542642 & [123] \\
\hline Echinoparyphium recurvatum & Lymnaea peregra & UK & AY168940 & - & {$[76]$} \\
\hline Echinoparyphium recurvatum & Sphaerium sp. & Norway & KY513266 & - & {$[122]$} \\
\hline Echinoparyphium recurvatum & Radix ovata & Slovakia & - & КT956913 & {$[126]$} \\
\hline Echinoparyphium rubrum & Helisoma trivolvis & USA & - & $\mathrm{JX} 262943$ & [129] \\
\hline Echinoparyphium sp. A & Not specified & Canada & МH369069 & - & {$[51]$} \\
\hline Echinoparyphium sp. Lineage 2 & Not specified & Canada & MH369107 & - & [51] \\
\hline Echinoparyphium sp. Lineage 3 & Helisoma trivolvis & USA & GQ463122 & - & {$[24]$} \\
\hline Echinoparyphium sp. Lineage 3/4 & Helisoma trivolvis & Canada & MH369158 & - & {$[51]$} \\
\hline Echinoparyphium sp. 1A & Not specified & Canada & MH369046 & - & {$[51]$} \\
\hline Echinoparyphium sp. 1A & Not specified & Canada & MH369047 & - & [51] \\
\hline Echinoparyphium sp. A2 & Physa gyrina & Canada & MH369190 & - & [51] \\
\hline Echinoparyphium sp. Lineage 2 & Not specified & Canada & MH369148 & - & [51] \\
\hline Echinoparyphium sp. A & Not specified & Canada & MH369081 & - & [51] \\
\hline Echinoparyphium sp. A & Not specified & Canada & MH369083 & - & [51] \\
\hline Echinoparyphium sp. A & Not specified & Canada & MH369051 & - & {$[51]$} \\
\hline Echinoparyphium sp. A & Not specified & Canada & MH369011 & - & {$[51]$} \\
\hline Echinoparyphium sp. B & Stagnicola elodes & Canada & МH368969 & - & [51] \\
\hline Echinoparyphium sp. C & Stagnicola elodes & Canada & MH369088 & - & [51] \\
\hline Echinoparyphium sp. D & Stagnicola elodes & Canada & MH369189 & - & [51] \\
\hline Echinoparyphium sp. E & Not specified & Canada & MH369109 & - & {$[51]$} \\
\hline Echinoparyphium sp. 1A & Not specified & Canada & MH369089 & - & {$[51]$} \\
\hline Echinoparyphium sp. 1A & Not specified & Canada & MH369191 & - & [51] \\
\hline Echinoparyphium sp. 1B/A2 & Not specified & Canada & MH369181 & - & [51] \\
\hline Echinoparyphium sp. Lineage 1 & Ondatra zibethicus & USA & GQ463105 & - & [24] \\
\hline Echinoparyphium sp. Lineage 3/4 & Helisoma trivolvis & Canada & MH369130 & - & [51] \\
\hline Echinoparyphium sp. & Bulinus tropicus & Kenya & MK534394 & - & {$[84]$} \\
\hline Echinoparyphium poulini & Cygnus atratus & New Zealand & KY436403 & - & {$[45]$} \\
\hline Echinoparyphium poulini & Cygnus atratus & New Zealand & - & KY436409 & {$[45]$} \\
\hline Echinostoma bolschewense & Viviparus acerosus & Slovakia & - & KP065592 & [46] \\
\hline Echinostoma bolschewense & Viviparus acerosus & Slovakia & KP065623 & - & [46] \\
\hline Echinostoma caproni & Rattus norvegicus & Egypt & AJ564378 & - & $\begin{array}{l}\text { Marcilla et al. } \\
\text { (unpublished) }\end{array}$ \\
\hline Echinostoma caproni & Biomphalaria sudanica & Kenya & MK534417 & - & {$[84]$} \\
\hline Echinostoma caproni & Biomphalaria sudanica & Kenya & - & MK482501 & [84] \\
\hline Echinostoma deserticum & - & Niger & AF025836 & - & [97] \\
\hline Echinostoma friedi & Mesocricetus auratus & Spain & AJ564379 & - & $\begin{array}{l}\text { Marcilla et al. } \\
\text { (unpublished) }\end{array}$ \\
\hline Echinostoma IG & Radix peregra & Iceland & KC618448 & - & [48] \\
\hline Echinostoma IG & Radix auricularia & Germany & KC618449 & - & {$[48]$} \\
\hline Echinostoma IG & Radix auricularia & Germany & - & KP065606 & [46] \\
\hline Echinostoma miyagawai & Anas platyrhynchos & New Zealand & KY436400 & - & {$[45]$} \\
\hline Echinostoma miyagawai & Anas platyrhynchos & Ukraine & - & KT956916 & {$[126]$} \\
\hline Echinostoma nasincovae & Planorbarius corneus & Czech Republic & KP065676 & - & [46] \\
\hline Echinostoma nasincovae & Planorbarius corneus & Czech Republic & - & KP065603 & [46] \\
\hline Echinostoma novaezealandense & Branda canadensis & New Zealand & AF026289 & - & [97] \\
\hline Echinostoma novaezealandense & Anas platyrhynchos & New Zealand & KY436399 & - & [45] \\
\hline Echinostoma novaezealandense & Cygnus atratus & New Zealand & - & KY436407 & [45] \\
\hline Echinostoma paraensei & - & Brazil & AF025834 & - & [97] \\
\hline
\end{tabular}


Table 4. (Continued)

\begin{tabular}{|c|c|c|c|c|c|}
\hline Species & Host species* & Locality & $\begin{array}{l}\text { GenBank } \\
\text { ID, nad } 1\end{array}$ & $\begin{array}{c}\text { GenBank } \\
\text { ID, } 28 S\end{array}$ & Reference \\
\hline Echinostoma paraensei & Glyptophysa sp. & Australia & AF026282 & - & [97] \\
\hline Echinostoma paraensei & "hamster" & USA & - & EU025867 & $\begin{array}{l}\text { Brant et al. } \\
\text { (unpublished) }\end{array}$ \\
\hline Echinostoma paraulum & Lymnaea stagnalis & Germany & KP065681 & - & [46] \\
\hline Echinostoma paraulum & Lymnaea stagnalis & Germany & - & KP065604 & [46] \\
\hline Echinostoma revolutum & Lymnaea elodes & USA & GQ463090 & - & [24] \\
\hline Echinostoma revolutum & Ondatra zibethicus & USA & JQ670862 & - & {$[25]$} \\
\hline Echinostoma revolutum & Aythya collaris & USA & - & КT956915 & {$[126]$} \\
\hline Echinostoma revolutum s. str. & Anas platyrhynchos & Bangladesh & LC224099 & - & [96] \\
\hline Echinostoma revolutum s. str. & Radix peregra & Iceland & KC618451 & - & [48] \\
\hline Echinostoma revolutum s. str. & Lymnaea stagnalis & Finland & KP065655 & - & [46] \\
\hline Echinostoma revolutum s. str. & Aythya fuligula & Czech Republic & - & KP065596 & [46] \\
\hline Echinostoma revolutum Lineage B & Stagnicola elodes & Canada & MH369221 & - & [51] \\
\hline Echinostoma robustum/E. friedi & Lymnaea elodes & USA & GQ463053 & - & [24] \\
\hline Echinostoma robustum/E. friedi & Lymnaea elodes & USA & GQ463054 & - & {$[24]$} \\
\hline Echinostoma trivolvis & - & North America & AF025831 & - & {$[97]$} \\
\hline Echinostoma trivolvis & Mesocricetus auratus & UK & - & AY222246 & [106] \\
\hline Echinostoma trivolvis & Ondatra zibethicus & USA & JQ670852 & - & [25] \\
\hline Echinostoma trivolvis Lineage A & Helisoma trivolvis & Canada & MH369198 & - & [51] \\
\hline Echinostoma trivolvis Lineage B & Ondatra zibethicus & USA & JQ670857 & - & {$[25]$} \\
\hline Euparyphium capitaneum & Anhinga anhinga & USA & - & KP009620 & {$[79]$} \\
\hline Hypoderaeum conoideum & Anas platyrhynchos & Ukraine & - & KT956918 & {$[126]$} \\
\hline Hypoderaeum Lineage 1 & Stagnicola elodes & Canada & MH368958 & - & {$[51]$} \\
\hline Hypoderaeum Lineage $1 / 2$ & Stagnicola elodes & Canada & MH369080 & - & {$[51]$} \\
\hline Isthmiophora melis & Nyctereutes procyonoides & Ukraine & - & AF151941 & {$[127]$} \\
\hline Moliniella anceps & Planorbarius corneus & Lithuania & - & KT956921 & [126] \\
\hline Neoacanthoparyphium echinatoides & Viviparus acerosus & Slovakia & - & KT956922 & {$[126]$} \\
\hline Neopetasiger islandicus & Planorbula armigera & Canada & KT831342 & - & {$[52]$} \\
\hline Neopetasiger islandicus & Aechmophorus occidentalis & USA & - & КT956924 & {$[126]$} \\
\hline Neopetasiger neocomense & Podiceps cristatus & Czech Republic & JQ425591 & - & {$[47]$} \\
\hline Neopetasiger sp. & Podiceps grisegena & USA & - & KT956925 & {$[126]$} \\
\hline Neopetasiger sp. 4 & Helisoma trivolvis & Canada & KT831343 & - & {$[52]$} \\
\hline Neopetasiger sp. 4 & Helisoma trivolvis & Canada & MH369313 & - & {$[51]$} \\
\hline Patagifer vioscai & Eudocimus albus & USA & - & КT956946 & {$[126]$} \\
\hline Patagifer sp. 1 & Biomphalaria sudanica & Kenya & MK534424 & - & [84] \\
\hline Petasiger islandicus & Gyraulus cf. laevis & Iceland & JQ425588 & - & [47] \\
\hline Petasiger islandicus & Gyraulus cf. laevis & Iceland & - & JQ425592 & {$[47]$} \\
\hline Petasiger exaeretus & Phalacrocorax carbo & Ukraine & - & КT956923 & [126] \\
\hline Petasiger $\mathrm{sp} .1$ & Gyraulus albus & Germany & KM191808 & - & [118] \\
\hline Petasiger sp. 1 & Planorbis planorbis & Czech Republic & - & KM191800 & [118] \\
\hline Petasiger sp. 2 & Gyraulus albus & Germany & KM191810 & - & [118] \\
\hline Petasiger sp. 2 & Gyraulus albus & Germany & - & KM191802 & [118] \\
\hline Petasiger sp. 3 & Gyraulus albus & Germany & KM191812 & - & [118] \\
\hline Petasiger sp. 3 & Planorbis planorbis & Germany & - & KM191804 & [118] \\
\hline Petasiger sp. 4 & Gasterosteus aculeatus & Canada & KM191817 & - & [118] \\
\hline Petasiger $\mathrm{sp} .4$ & Gasterosteus aculeatus & Canada & - & KM191807 & [118] \\
\hline Ribeiroia ondatrae & Pelecanus erythrorhynchos & USA & - & KT956956 & {$[126]$} \\
\hline
\end{tabular}

\footnotetext{
* Host names are used as in publications.
}

Soldánová \& Kostadinova, 2015 recently described in Europe [32]; and two isolates collected from $R$. balthica in Iceland and one isolate from M. glutinosa in Ireland clustered with an unidentified species of Echinostoma sp. IG sensu Georgieva et al. [48] previously reported in Iceland, Germany and Wales (UK) [48]. The sequence divergence between isolates of Ec. nasincovae was $0.7 \%$ (3 nt), between isolates of Ec. revolutum s. str. it was $0-1.6 \%(0-7 \mathrm{nt})$, between isolates of Ec. revolutum it was
$0-0.9 \%$ ( $0-4 \mathrm{nt})$ and between isolates of Echinostoma sp. IG it was $0.2-1.2 \%$ (1-5 nt) (Alignment 2; $430 \mathrm{nt}$ ).

Both BI and ML analyses based on nad1 sequences of Neopetasiger spp. in our third alignment resulted in consensus trees with similar topologies (Fig. 3). Four isolates of Neopetasiger collected in the present study in Gyraulus cf. parvus and Planorbis planorbis (Linnaeus) in Iceland and Ireland, respectively fall into two strongly supported clades 


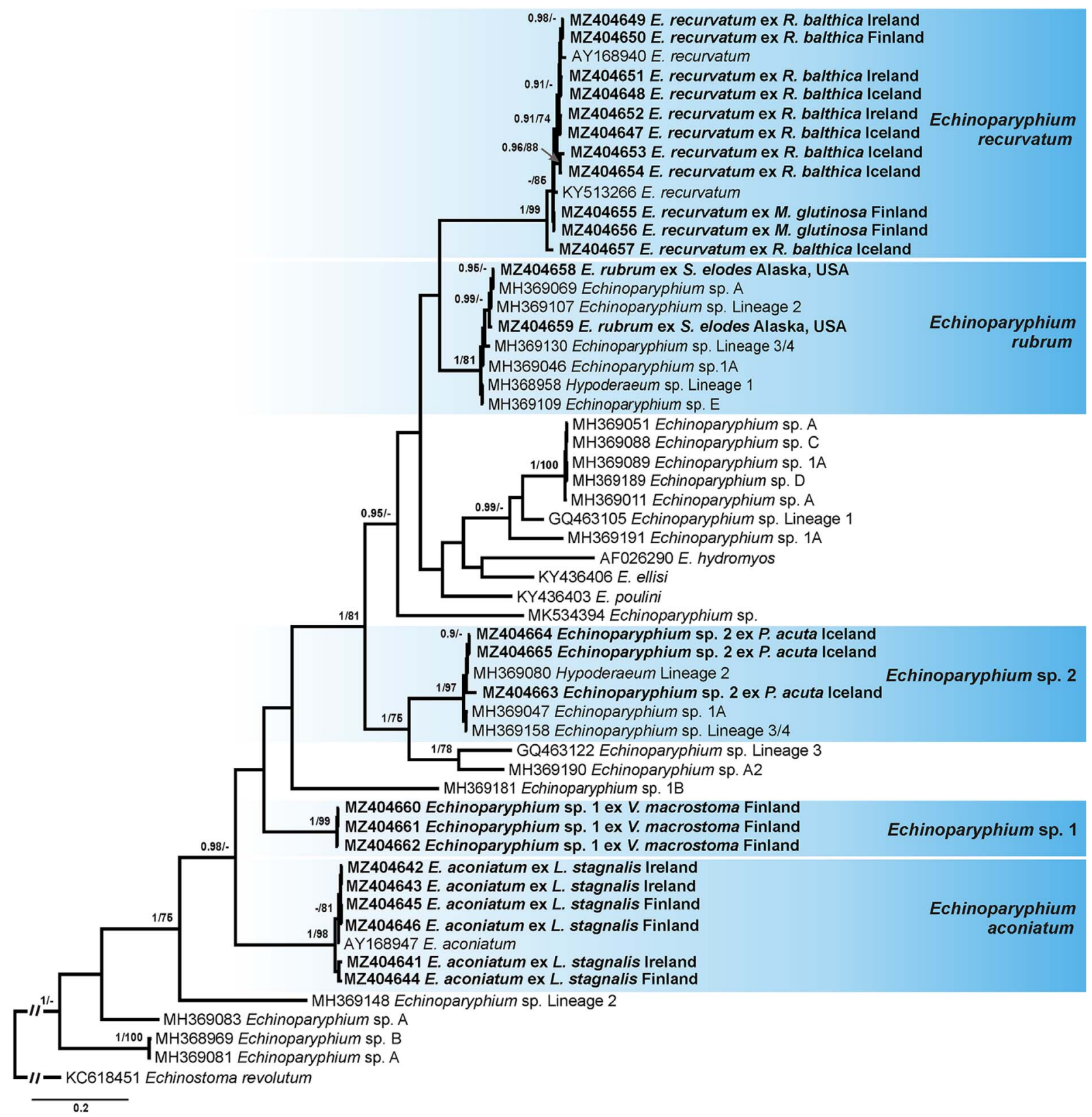

Figure 1. Phylogram from Bayesian inference (BI) analysis based on the nad1 sequences of Echinoparyphium spp. Nodal support values are given as BI/ML (maximum likelihood). Support values lower than 0.90 (BI) and 70 (ML) are not shown. The scale-bar indicates the expected number of substitutions per site. Newly generated sequences are highlighted in bold. Coloured rectangles indicate species identified in this study.

(Fig. 3). Three identical isolates representing species of N. islandicus Kostadinova \& Skírnisson, 2007 clustered with two isolates of the same species from G. cf. laevis and Planorbula armigera (Say) in Iceland and Canada, respectively (Fig. 3). The intraspecific divergence between the four European isolates of this species was 0-0.3\% (0-1 nt) (Alignment 3; 402 nt). Isolates from North America differed from the European isolates by $2.8-3.1 \%(10-11 \mathrm{nt})$. The remaining isolate collected in Ireland formed a separate branch within the clade consisting of Neopetasiger sp. 1 and Neopetasiger sp. 2 previously reported from G. albus in Germany [118]. The interspecific divergence between sequences of Neopetasiger sp. 5 and the other species of this genus included in the analyses was 18.5-32.5\% (66$116 \mathrm{nt})$. Neopetasiger sp. 2 appeared to be more closely related to Neopetasiger sp. 5, whereas N. neocomense showed the highest sequence divergence.

Comparison of nad 1 sequence data between the isolate of Hypoderaeum conoideum (Bloch, 1782) of the present study and two isolates of this species available in GenBank (AY168949 [76]; and MH282580 [95]) showed low divergence (0.2-0.5\%,1-2 nt), confirming identification of our isolate as H. conoideum. 


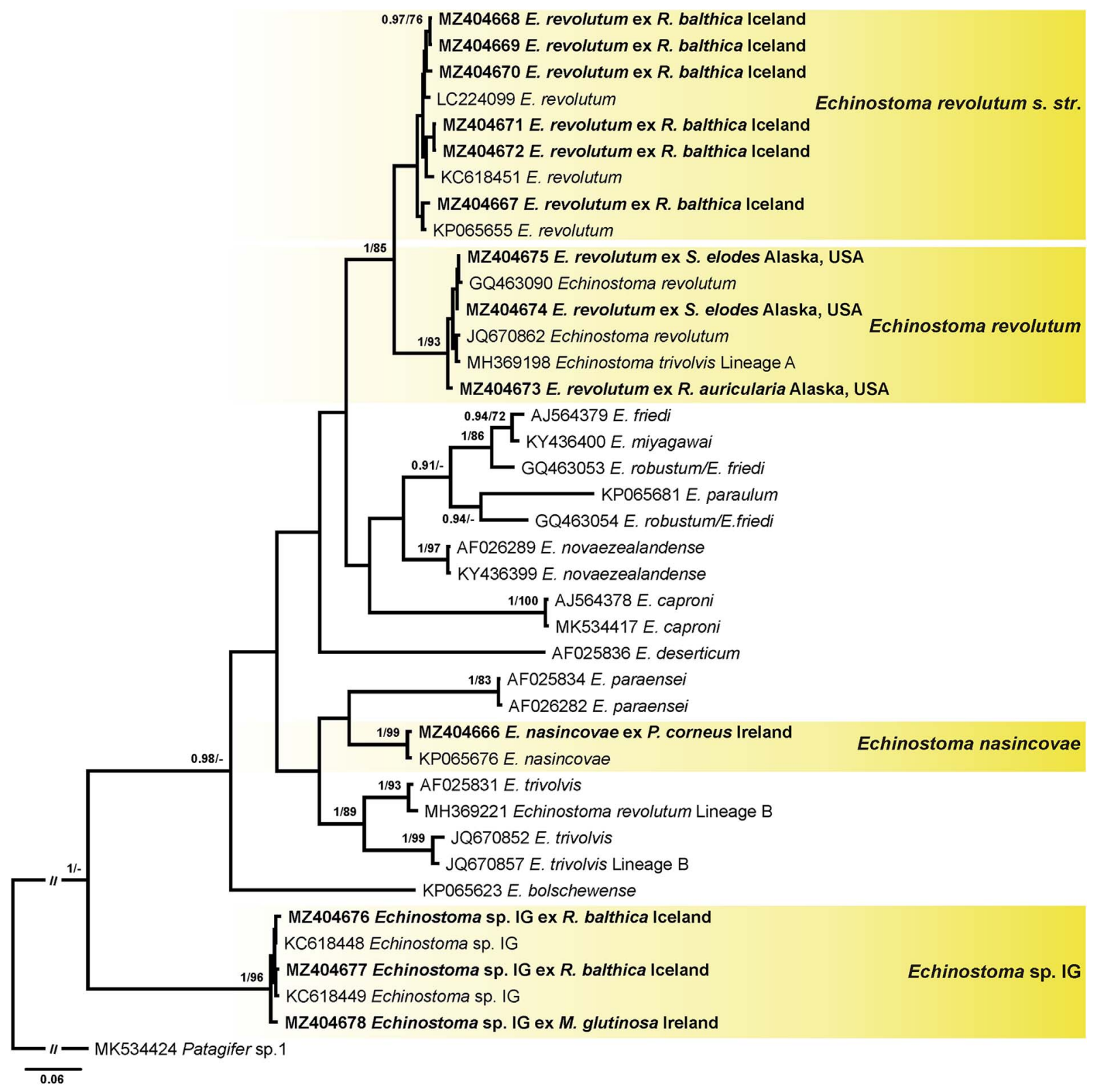

Figure 2. Phylogram from Bayesian inference (BI) analysis based on the nad1 sequences of Echinostoma spp. Nodal support values are given as BI/ML (maximum likelihood). Support values lower than 0.90 (BI) and 70 (ML) are not shown. The scale-bar indicates the expected number of substitutions per site. Newly generated sequences are highlighted in bold. Coloured rectangles indicate species identified in this study.

The results of phylogenetic analyses based on $28 \mathrm{~S}$ $r D N A$ sequences (fourth alignment) confirmed the species delineation and identification based on nad1 data analyses. The novel sequences clustered within the four clades presented (Fig. 4). Clade 1 included sequences of Echinoparyphium spp. and $H$. conoideum. Our sequences of E. aconiatum, E. recurvatum, E. rubrum and $H$. conoideum clustered with sequences of the same species retrieved from GenBank. The isolate of Echinoparyphium sp. 1 clustered with the isolate of E. mordwilkoi Skrjabin, 1915 with strong support (1/100), while the sequence divergence between these isolates was $0.6 \%$ (7 nt) demonstrating that they represent different species. The isolate of Echinoparyphium sp. 2 clustered with isolates of E. ellisi
(Johnston \& Simpson, 1944), and the sequences of these isolates were identical.

Clade 2 consisted of two isolates of $M$. anceps and two isolates of an unidentified species Echinostomatidae gen. sp. The isolate of $M$. anceps in our study was collected from the snail Stagnicola fuscus (C. Pfeiffer) in Ireland and two isolates of Echinostomatidae gen. sp. were collected from L. stagnalis in Finland. The sequence divergence between the two species within the $28 S \mathrm{rDNA}$ dataset was $1.2 \%$ (13 nt) and within the nad 1 dataset it was $22.5 \%$ (97 nt).

Clade 3 included sequences of Echinostoma and sequences of Neoacanthoparyphium, Artyfechinostomum and Patagifer at basal position. Our sequences of Ec. nasincovae, Ec. revolutum 


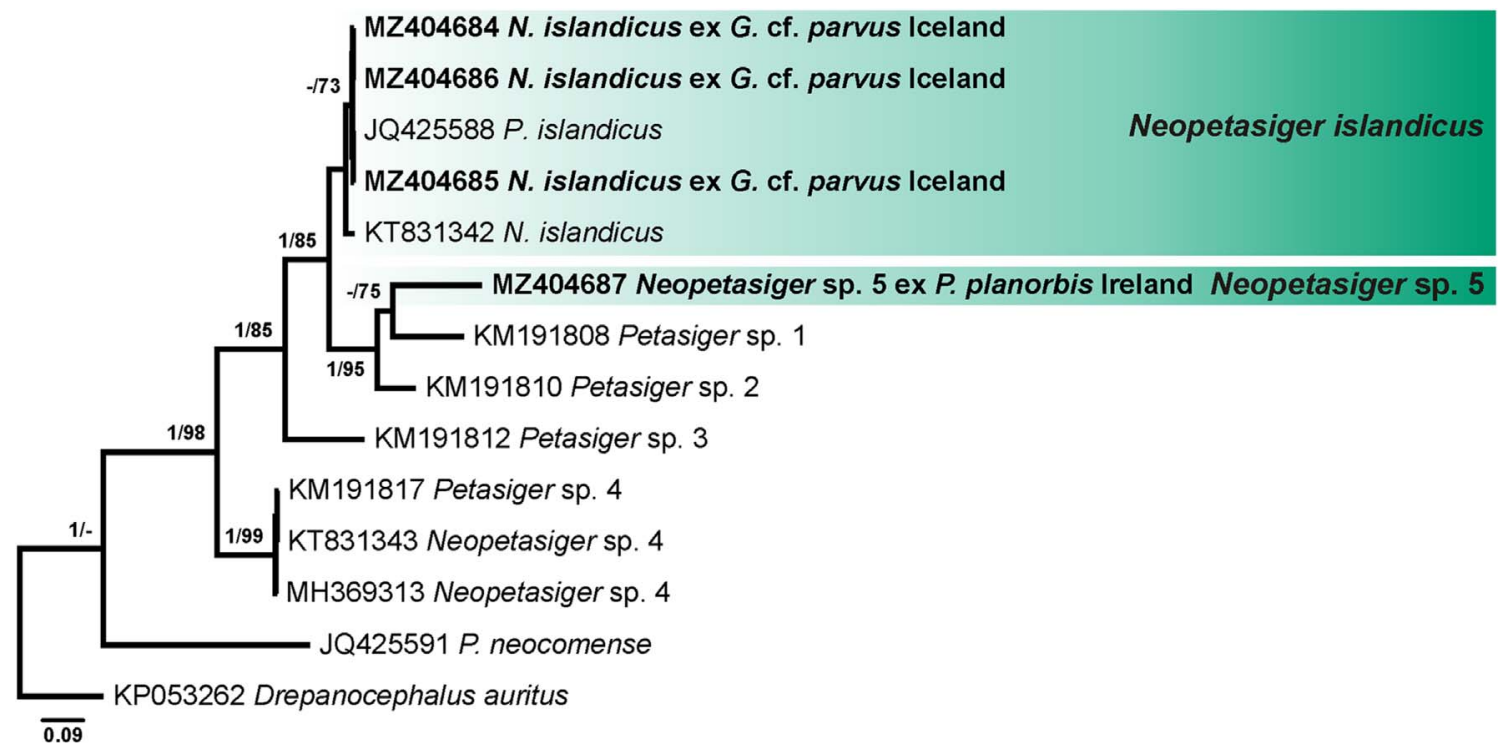

Figure 3. Phylogram from Bayesian inference (BI) analysis based on the nad1 sequences of Neopetasiger spp. Nodal support values are given as BI/ML (maximum likelihood). Support values lower than 0.90 (BI) and 70 (ML) are not shown. The scale-bar indicates the expected number of substitutions per site. Newly generated sequences are highlighted in bold. Coloured rectangles indicate species identified in this study.

s. str., Ec. revolutum, and Echinostoma sp. IG clustered into a strongly supported clade (1/97) with the sequences of corresponding species obtained from GenBank.

Within Clade 4, our isolates of $N$. islandicus and Neopetasiger sp. 5 clustered in a strongly supported subclade $(1 / 85)$ with isolates representing members of the genus Neopetasiger.

Based on the results of molecular identification, our samples represented 14 species belonging to six genera: Echinoparyphium (E. aconiatum, E. recurvatum, E. rubrum, Echinoparyphium sp. 1 and Echinoparyphium sp. 2), Echinostoma (Ec. nasincovae, Ec. revolutum s. str., Ec. revolutum and Echinostoma sp. IG), Neopetasiger (N. islandicus and Neopetasiger sp. 5), Hypoderaeum (H. conoideum), Moliniella (M. anceps) and one unidentified species Echinostomatidae gen. sp.

The incorporation of the nad 1 sequences of echinostomes (Echinoparyphium, Echinostoma and Hypoderaeum) published by Gordy and Hanington [51] in our analyses demonstrated numerous incorrect taxonomic annotations. In particular, (i) different names were used for the same species (Fig. 1, clades of "E. rubrum", "Echinoparyphium sp. 2" and clade with Echinoparyphium sp. A, 1A, C, D, Lineage A); (ii) the same name was used for different species (Fig. 1, Echinoparyphium sp. 1A (MH369046 and MH369047), and Echinoparyphium sp. A (MH369069, MH369051, MH369083 and MH369081)); and (iii) different species names for sequences have the same GenBank accession number (i.e., MH369130 and MH369158 correspond to Echinoparyphium sp. Lineage 3 and Echinoparyphium sp. Lineage 4; MH369080 corresponds to Hypoderaeum sp. Lineage 1 and Hypoderaeum sp. Lineage 2). Our analyses demonstrated that the genus of cercariae reported as Hypoderaeum sp. Lineages 1 and 2 (MH368958 and MH369080) was misidentified. These cercariae belong to the species of Echinoparyphium (Fig. 1). Additionally, the previous identifications of Echinostoma spp. were not followed (Fig. 2, see clades of "Ec. revolutum" and "Ec. trivolvis"). Another problem was related to the data of the host range of echinostomes. Although the species of snail hosts were provided in the paper, these names were not associated with the specific isolates, which precludes identification of the host of each species considering that some of the isolates were misidentified.

A total of $14 \operatorname{cox} 1(n=4)$ and ITS2 $(n=10)$ sequences were generated for snail isolates (Table 3). Molecular identification was achieved via comparison of novel sequences with those previously published and available in GenBank. Generally, the sequence divergence was low corresponding to the intraspecific level. The cox 1 sequence of $P$. acuta from Iceland differed from $P$. acuta from Greece (KF737936; [4]) and the USA (KJ769124; [57]) by $0.2-1.4 \%$ (1-9 nt). The ITS2 sequence of $P$. acuta from Iceland differed from $P$. acuta from Mexico (HQ283272; [20]) and the USA (KF316326, KF316328; [102]) by 1-2.1\% (3-6 nt). The $\operatorname{cox} 1$ sequence of our isolate $M$. glutinosa collected in Ireland differed from $M$. glutinosa in the USA (EU818798; [3]) and in Europe (DQ980191; [107]) by $0.3 \%$ (1 nt). The ITS2 sequence of our isolate and a sequence of $M$. glutinosa from the UK (MN644819; [114]) were identical. The identification of $R$. balthica is described in Kudlai et al. [78]. Four additional sequences of $R$. balthica from Iceland were obtained in this study. The intraspecific divergence was $0-0.2 \%(0-1 \mathrm{nt})$. These sequences were compared to the ITS2 sequence from Iceland (HQ003227-HQ003229; [66]), Norway (KY513276KY513278; [122]), UK (KT337593, KT337601; [85]), Germany (HE573078; [116]), Switzerland (HE573081; [116]) and Spain (HE573099; [116]). The sequence divergence was low (0-0.7\% (2 nt)), corresponding to the intraspecific level. 


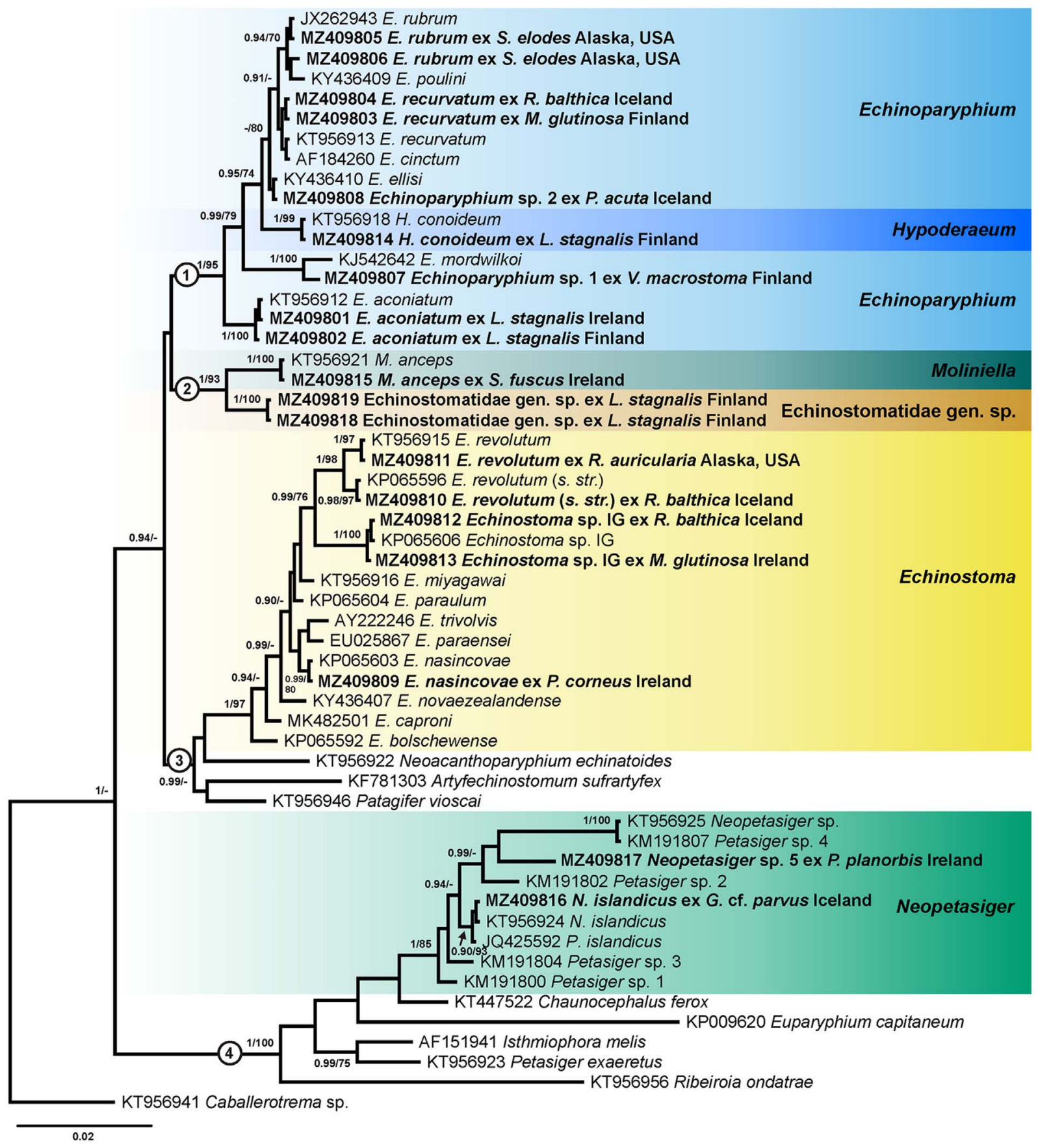

Figure 4. Phylogram from Bayesian inference (BI) analysis based on the $28 S$ sequences of the representatives of the Echinostomatidae. Nodal support values are given as BI/ML (maximum likelihood). Support values lower than 0.90 (BI) and 70 (ML) are not shown. The scale-bar indicates the expected number of substitutions per site. Newly generated sequences are highlighted in bold. Coloured rectangles indicate species identified in this study. The numbers $1,2,3$ and 4 refer to the clades discussed in the text.

The intraspecific difference between $\operatorname{cox} 1$ sequences of Gyraulus cf. parvus generated in our study was $0.4 \%$ (2 nt). They differed from sequences of Gyraulus parvus from the USA (LC429535; [115]) and from Canada (MG421286, MG421343, MG421564; [134]) by 4-6.1\% (22-33 nt). The ITS2 sequences of Gyraulus cf. parvus generated in the present study were identical and differed from a sequence of $G$. parvus in GenBank from Canada (MN644828; [114]) by $0.5 \%$ (3 nt).

\section{Morphological characterisation}

The morphology of all the present cercariae corresponds well to that of the family Echinostomatidae Looss, 1899 in the presence of a head collar with a row of collar spines larger than tegumental spines, the main ascending excretory channels filled with refractive granules, and a simple tail with or without fin-folds [34, 35, 41, 62, 73]. Species and genera are listed 
alphabetically. Descriptions are provided only for newly recorded species (Echinoparyphium sp. 1, Ec. revolutum, Neopetasiger sp. 5 and Echinostomatidae gen. sp.) and those not previously associated with DNA sequences (E. recurvatum, E. rubrum and Echinoparyphium sp. 2).

\section{Echinostomatidae Looss, 1899}

\section{Echinoparyphium Dietz, 1909}

\section{Echinoparyphium aconiatum Dietz, 1909}

First intermediate host: Lymnaea stagnalis (Linnaeus) (Gastropoda: Lymnaeidae).

Localities: Hackett Pond, Killeeneen, Lough Corrib, Ireland; Huumonjärvi, Finland.

Representative DNA sequences: MZ404641-MZ404646 (nad1); MZ409801, MZ409802 (28S).

Remarks: The new material from Ireland and Finland keys down to E. aconiatum in the key of Faltýnková et al. [34]. Echinoparyphium aconiatum is a parasite of anatid birds (ducks, geese) in the Holarctic [119]; in Europe, its larval stages are among those most commonly found in L. stagnalis [33, 34]. This is the first species record for Ireland and the species' most western distribution in Europe.

\section{Echinoparyphium recurvatum (Linstow, 1873) Dietz, 1909}

First intermediate hosts: Radix balthica (Linnaeus), Myxas glutinosa (O.F. Müller) (Gastropoda: Lymnaeidae).

Localities: Lake Ashildarholtsvatn, Lake Rauðavatn, pond at Nordic House, Iceland; Lough Corrib, Lough Mask, Ireland; Lake Konnevesi, Finland.

Representative DNA sequences: MZ404647-MZ404657 (nad1); MZ409803, MZ409804 (28S).

Cercaria (Figs. 5A-5C, 7A-7C)

(Description and measurements based on live material of six specimens; not all specimens contributed a data point to all metrical variables): Body elongate-oval, with maximum width just anterior to ventral sucker, $327-376 \times 168-201$ $(351 \times 185)$. Tegument thick, armed with robust, triangular, sharply pointed tegumental spines (see arrows Fig. 7C), 4-6 (5) long, becoming more slender and sharper posteriorly; extending ventrally from behind collar up to half-distance between ventral sucker and posterior body extremity; dorsally extending up to anterior level of ventral sucker. Collar well developed, 58-79 × 110-141 $(68 \times 126)$, with 45 , slender, sharply pointed collar spines (see Fig. 5C, arrowheads Fig. 7C). Collar spine arrangement: on each side four angle spines, 12-16 (14) long; 37 marginal spines in double row; lateral spines 12-16 (14) long; dorsal aboral spines 12-16 (14), dorsal oral spines 10-15 (12) long, smaller than aboral spines (see Fig. 5C). Oral sucker ventro-subterminal, rounded, muscular, 41-56 × 48-64 $(49 \times 55)$. Ventral sucker rounded to transversely-oval, muscular, postequatorial, outer margin surrounded by small inconspicuous tegumental fold, 53-70 $\times$ 53-82 $(61 \times 68)$, larger than oral sucker; sucker width ratio 1:0.97-1.51 (1.23). Prepharynx distinct, narrow, highly contractile, slightly shorter than pharynx, 4-16 (10) long. Pharynx oval to elongate-oval, muscular, 24-33 × 16-28 $(28 \times 21)$. Oesophageal primordium long; intestinal bifurcation anterior to ventral sucker. Caecal primordia reach to anterior level of excretory vesicle or up to posterior body extremity. Cystogenous gland-cells numerous, with fine granular contents, extending from posterior level of pharynx to posterior extremity of body, most prominent in two lateral and one median field. Penetration gland-cells indistinct, around oesophageal primordium, stain slightly with Neutral red, number could not be determined, outlets on dorsal lip of oral sucker. Genital anlagen consist of two compact, interconnected, transparent groups of small cells, located median, anterodorsal and posterior to ventral sucker. Excretory vesicle saccular, rounded, constricted anteriorly. Main collecting ducts ascending from constricted part of excretory vesicle, ducts dilated between level of pharynx and anterior level of ventral sucker, densely filled with c. 105-200 small refractive excretory granules of similar size, diameter 3-5 (4), becoming smaller only anteriorly and posteriorly; ducts narrow and reflex at level of pharynx and lead backwards. Flame-cell formula $2[(3+3+3)+(3+3+$ $3+3+3)]=48$. Excretory pore at junction of body and tail; caudal excretory duct bifurcates at $\mathrm{c}$. the first quarter of tail length into two oblique branches opening laterally. Tail simple, devoid of fin-folds, of similar length as body or longer when live, muscular, contractile, with bluntly pointed tip, 399-489 × 45-67 $(447 \times 55)$.

Measurements of cercariae fixed in cold formalin (based on 25 specimens; not all specimens contributed a data point to all metrical variables): Body 219-319 × 123-196 (275 × 147). Collar 46-73 × 76-118 $(59 \times 90)$. Oral sucker $35-52 \times$ 39-54 (44 × 47). Ventral sucker 41-67 × 48-82 $(54 \times 62)$. Sucker width ratio 1:1.02-1.58 (1:1.31). Prepharynx 3-14 (8) long. Pharynx $18-20 \times 13-21(23 \times 16)$. Tail $269-451 \times$ 36-53 $(383 \times 44)$. TL/BL ratio 0.96-1.73 (1.40).

Redia (Fig. 5D)

(Description and measurements based on 10 specimens of live daughter-rediae ex $R$. balthica from Finland): Body with orange-brownish pigment, elongate, tapered anteriorly and posteriorly, $2100-3575 \times 300-375(2935 \times 330)$. Collar well pronounced, entire, slightly narrower than body. Birth pore just posterior to collar. Two prominent locomotory appendages present at about $2 / 3$ of body length. Pharynx large, rounded, muscular, $300-400 \times 325-425(365 \times 383)$. Intestine short, sac-like, in c. first fifth of body.

Remarks: The morphology of the present cercariae agrees well with that of the genus Echinoparyphium Dietz, 1909 in the presence of sharply pointed collar spines, four angle spines, marginal spines arranged in a double row, dorsal spines differing in size, tail devoid of fin-folds, numerous ( $>100)$ and relatively small excretory granules $(<6 \mu \mathrm{m})$ in main collecting ducts [34, 53]. Following the key of Faltýnková et al. [34], the cercariae in our material key down to E. recurvatum in the presence of 45 collar spines and in the size of body (being close to the range of $200-250 \mu \mathrm{m}$ ) as well as the characters listed above. Grabda-Kazubska \& Kiseliene [53] who redescribed the cercaria of E. recurvatum ex Radix spp. and distinguished it from the form occurring in planorbid snails (E. pseudorecurvatum Kiseliene \& Grabda-Kazubska, 1990), consider the description of E. recurvatum s. str. ex Lymnaea peregra (sic) provided by Rašín [111] as the most comprehensive, and they view his material as the basis for recognition of E. recurvatum s. str., because Rašín [111] completed the whole 

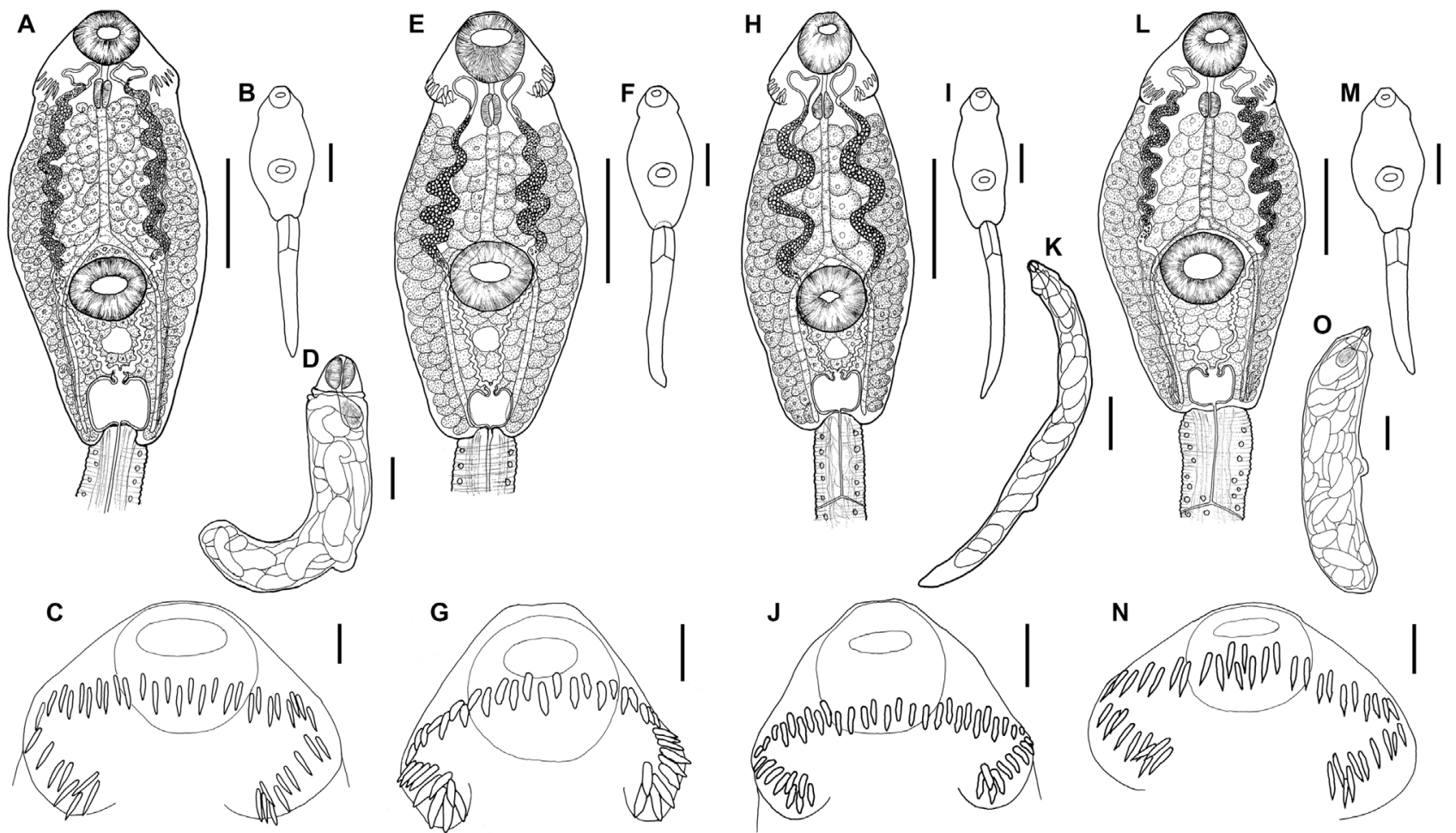

Figure 5. Drawings of cercariae. Echinoparyphium recurvatum ex Radix balthica. (A) body, ventral view, (B) total view, (C) head collar with collar spines, (D) redia, lateral view. Echinoparyphium rubrum ex Stagnicola elodes. (E) body, ventral view, (F) total view, (G) head collar with collar spines. Echinoparyphium sp. 1 ex Valvata macrostoma. (H) body, ventral view, (I) total view, (J) head collar with collar spines, (K) redia, lateral view. Echinoparyphium sp. 2 ex Physa acuta. (L) body, ventral view, (M) total view, (N) head collar with collar spines, (O) redia, lateral view. Scale-bars: A, B, E, F, H, L, M, $100 \mu \mathrm{m} ; \mathrm{C}, \mathrm{G}, \mathrm{J}, \mathrm{N}, 20 \mu \mathrm{m}$; D, I, K, O, $200 \mu \mathrm{m}$.
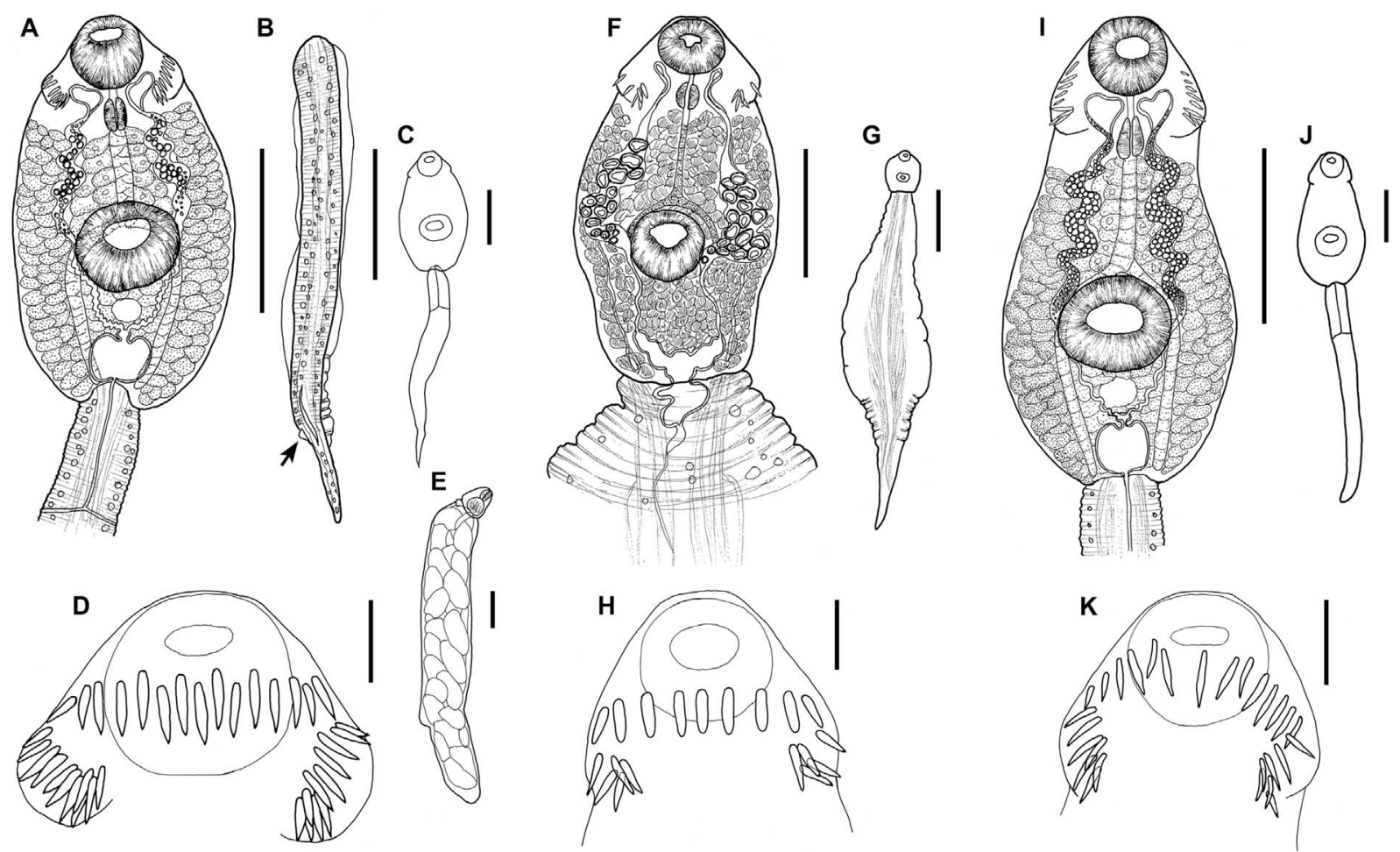

Figure 6. Drawings of cercariae. Echinostoma revolutum ex Radix auricularia. (A) body, ventral view, (B) tail with fin-folds, lateral view, (C) total view, (D) head collar with collar spines, (E) redia, lateral view. Neopetasiger sp. 5 ex Planorbis planorbis. (F) body, ventral view, (G) total view, (H) head collar with collar spines. Echinostomatidae gen. sp. ex Lymnaea stagnalis. (I) body, ventral view, (J) total view, (K) head collar with collar spines. Scale-bars: A, B, C, F, I, $100 \mu \mathrm{m} ; \mathrm{D}, \mathrm{H}, \mathrm{K}, 20 \mu \mathrm{m}$; E, G, J, $200 \mu \mathrm{m}$. 

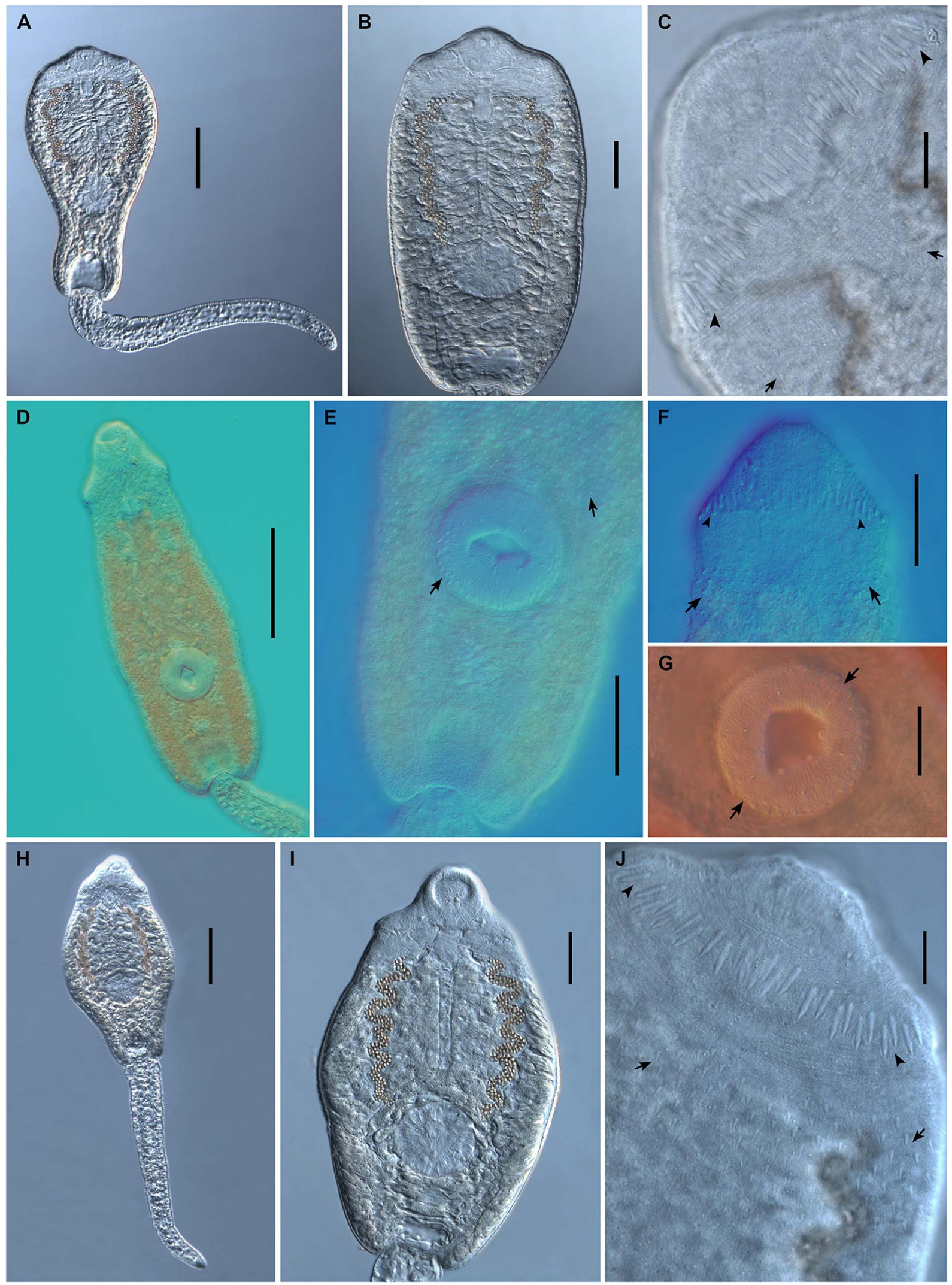

Figure 7. Photomicrographs of live cercariae of Echinoparyphium recurvatum ex Radix balthica. (A) body and tail, ventral view, (B) body, ventral view, (C) head collar, dorsal view, showing dorsal collar spines (arrowheads) and tegumental spines (arrows). Fixed cercariae of Echinoparyphium sp. 1 ex Valvata macrostoma. (D) total view, (E) ventral view with ventral sucker with tegumental spines and tegumental spines on body, (F) head collar, dorsal view, showing dorsal collar spines (arrowheads) and tegumental spines (arrows), (G) detail of ventral sucker with tegumental spines (arrows). Live cercariae of Echinoparyphium sp. 2 ex Physa acuta. (H) body and tail, ventral view, (I) body, ventral view, (J) head collar, dorsal view, showing dorsal collar spines (arrowheads) and tegumental spines (arrows). Scale bars: A, D, E, F, G, $\mathrm{H}, 100 \mu \mathrm{m}, \mathrm{B}, \mathrm{I}, 50 \mu \mathrm{m}, \mathrm{C}, \mathrm{J}, 20 \mu \mathrm{m}$. 
life-cycle of this species based on material from nature and from experiments.

The morphology of our cercariae agrees well with the description of Rašín [111], i.e. the dorsal oral collar spines are smaller than the dorsal aboral spines; the angle spines correspond in size $(12-16 \mu \mathrm{m}$ vs. $12-14 \mu \mathrm{m})$, while the aboral $(12-16 \mu \mathrm{m}$ vs. $13 \mu \mathrm{m})$ and oral spines $(10-15 \mu \mathrm{m}$ vs. $11 \mu \mathrm{m})$ are slightly larger. The excretory granules correspond in arrangement and size (3-5 $\mu \mathrm{m}$ vs. $5 \mu \mathrm{m})$. Also, the dimensions of cercariae (size of body, tail and collar) measured live agree. Our cercariae also agree with those described by GrabdaKazubska \& Kiseliene [53] in morphology of body and arrangement and size of collar spines and size of tegumental spines (4-6 $\mu \mathrm{m}$ vs. $5 \mu \mathrm{m})$. We update the distribution of tegumental spines, which are extending behind the ventral sucker ventrally and reach up to half-distance between ventral sucker and posterior extremity; dorsally they extend to the anterior level of the ventral sucker. There were different reports on the extent of the tegumental spines [111] as it is difficult to observe the minute spines in the posterior part of the body. Only the body length provided by Grabda-Kazubska \& Kiseliene [53] is slightly larger (319-420 (367) $\mu \mathrm{m})$ than our live and formalin fixed material, which could be due to the method of fixation (cercariae heat fixed and a drop of formalin added in [53]).

Echinoparyphium recurvatum and its life-cycle has been reported since the 1920's (see [53] for citations) resulting in many records from a wide variety of hosts from all over the world. There arose doubts about its identity, and already Odening [103, 104] and Grabda-Kazubska \& Kiseliene [53] claimed that the cosmopolitan E. recurvatum contained more than one species. Although Grabda-Kazubska \& Kiseliene [53] delineated E. recurvatum and clarified the identity of the species, there has so far been no description linked to molecular identification (i.e. Soldánová et al. [122], Kostadinova et al. [76], Tkach et al. [126] provided no morphological descriptions). Therefore, for the first time, we provide a morphological description linked to DNA sequence data, and we corroborate its wide distribution in Europe.

Grabda-Kazubska \& Kiseliene [53] who examined the chaetotaxy of $E$. recurvatum, found that the chaetotaxy of E. recurvatum ex $R$. ovata and L. stagnalis reported in Nezvalová [100] showed the same pattern; however, the groups of sensillae seemed to be incomplete. Therefore, they could not compare them fully with their material, and so we cannot conclude with certainty if E. recurvatum occurs in L. stagnalis. We only found E. recurvatum in R. balthica and M. glutinosa. Frolova [40] reported E. recurvatum from Karelia (Russia) in the snails M. glutinosa, Stagnicola palustris (O. F. Müller, 1774) and Radix ovata (syn. of R. balthica).

\section{Echinoparyphium rubrum (Cort, 1917)}

First intermediate host: Stagnicola elodes

(Say)

(Gastropoda: Lymnaeidae).

Locality: Tanana, pool on riverbank, Alaska, USA.

Representative DNA sequences: MZ404658, MZ404659

(nad1); MZ409805, MZ409806 (28S).

Cercaria (Figs. 5E-5G, 8A-8B)
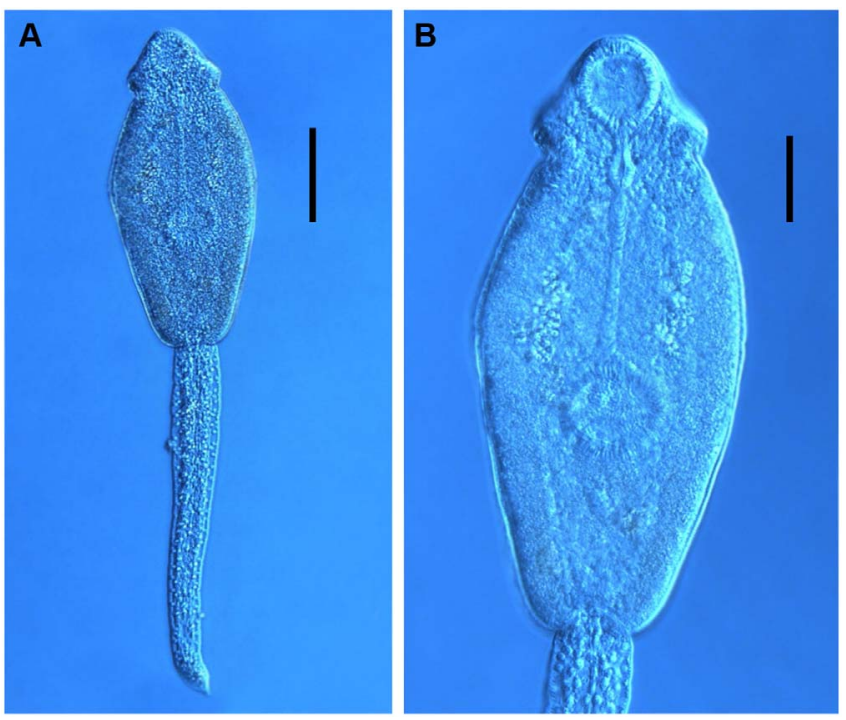

Figure 8. Photomicrographs of fixed cercariae of Echinoparyphium rubrum ex Stagnicola elodes. (A) total view, (B) body, ventral view. Scale bars: A, $100 \mu \mathrm{m}, \mathrm{B}, 50 \mu \mathrm{m}$.

(Description based on live material and 16 formalin fixed specimens): Body elongate-oval, with maximum width at anterior level of ventral sucker. Tegument thick, armed with robust, triangular, tegumental spines, partly embedded in tegument, becoming smaller and sharper posteriorly; ventrally extending to half distance between posterior level of ventral sucker and posterior extremity, dorsally extending up to posterior level of ventral sucker. Collar well developed, with 43, relatively robust, sharply pointed collar spines with short tip. Collar spine arrangement: on each side four angle spines; 35 marginal spines in double row, dorsal spines slightly smaller than lateral spines. Oral sucker ventro-subterminal, rounded, muscular. Ventral sucker rounded to transversely-oval, muscular, postequatorial, with a circle of six papillae, larger than oral sucker. Prepharynx very short. Pharynx oval to elongate-oval, muscular. Oesophageal primordium long; intestinal bifurcation just anterior to ventral sucker. Caecal primordia reach to posterior body extremity. Cystogenous gland-cells numerous, with fine granular contents, extending from posterior level of pharynx to posterior extremity of body. Penetration gland-cells indistinct, around oesophageal primordium, number could not be determined. Genital anlagen consist of two compact, interconnected, transparent groups of densely arranged cells, located median, anterodorsal and posterior to ventral sucker. Excretory vesicle saccular, rounded, constricted anteriorly. Main collecting ducts ascending from smaller constricted part of excretory vesicle, ducts dilated between level of pharynx and anterior level of ventral sucker, densely filled with 80-86 small refractive excretory granules of similar size (for diameter see below), becoming smaller only anteriorly and posteriorly; ducts narrow and reflex at level of pharynx and lead backwards. Flame-cell formula not determined. Excretory pore at junction of body and tail; caudal excretory duct bifurcates at $\mathrm{c}$. first quarter of tail length into two oblique branches opening laterally. Tail simple, devoid of finfolds, longer than body when fixed, muscular, contractile, with short, pointed tip. 
Measurements of cercariae fixed in cold formalin (based on 16 specimens; not all specimens contributed a data point to all metrical variables): Body 295-400 × 135-174 $(337 \times 155)$. Collar 64-113 × 81-120 $(70 \times 103)$. Oral sucker 49-60 $\times$ $46-59(55 \times 52)$. Ventral sucker 56-72 × 58-74 $(64 \times 64)$. Sucker width ratio 1:1.13-1.39 (1:1.25). Prepharynx 3-9 (6) long. Pharynx 18-31 × 15-26 $(25 \times 18)$. Collar spines: angle spine 15 long; lateral spines 10-14 (12) long; dorsal spines 11-12 (11) long. Diameter of excretory granules 3-5 (4). Tail $303-439 \times 44-58(391 \times 50)$. TL/BL ratio $1.10-1.40(1.26)$.

Remarks: The present cercariae agree well in their morphology with those of the genus Echinoparyphium in the presence of 43 collar spines with four angle spines and in the presence of numerous $(>80)$, relatively small $(<6 \mu \mathrm{m})$ excretory granules and a simple tail devoid of fin-folds, longer than body [73]. Cercaria rubra Cort, 1914 was first recorded by Cort [21] as metacercariae in the snail Campeloma subsolidum Antony (Viviparidae) in Connecticut, USA, therefore it is impossible to compare the original material. The entire life-cycle of E. rubrum has been elucidated experimentally and all developmental stages were described by Kanev et al. [67], alas, without molecular genetic analyses. The general morphology of the present cercariae is similar to those described by Kanev et al. [67], who obtained them experimentally from Physa gyrina Say and $P$. occidentalis (syn. of $P$. gyrina). The body dimensions of our cercariae (fixed in $4 \%$ formalin solution) are similar to those provided by Kanev et al. [67]; the size of body overlaps, although the body length in our material is slightly shorter (295-400 $\mu \mathrm{m}$ vs. $380-550 \mu \mathrm{m}$ ) as well as the tail length (303-439 $\mu \mathrm{m}$ vs. 390-560 $\mu \mathrm{m}$ ); however, the prepharynx in our material is much shorter (3-9 $\mu \mathrm{m}$ vs. $30 \mu \mathrm{m})$.

Metacercariae of E. rubrum were recorded by Pulis et al. [109] from the wood frog, Lithobates sylvaticus (LeConte) in the Northern Great Plains, and cercariae from Helisoma trivolvis were recorded by Tkach et al. [129] in Minnesota, USA. Gordy \& Hanington [51] recorded cercariae (nad1, matching our sequences of E. rubrum, see above) in lakes in Alberta, Canada, thus indicating that this species is most probably common and widely distributed in the northern USA and in Canada up to Alaska. As evidenced by previous and the present study, surprisingly, the first intermediate host spectrum is encompassing three families of snails, i.e. the physid Physa spp. obtained experimentally by Kanev et al. [67], the planorbid Helisoma [129] and the lymnaeid S. elodes in the present study.

\section{Echinoparyphium sp. 1}

First intermediate host: Valvata macrostoma Mörch (Gastropoda: Valvatidae).

Locality: Lake Konnevesi, Finland.

Representative DNA sequences: MZ404660-MZ404662 (nad1); MZ409807 (28S).

Cercaria (Fig. 5H-5J, 7D-7G)

(Description based on live material and six formalin fixed specimens): Body elongate-oval, maximum width just anterior to ventral sucker. Tegument thick, covered with short, robust, triangular, bluntly pointed tegumental spines becoming smaller posteriorly; spines extending from some distance posterior to collar to posterior level of ventral sucker ventrally; dorsally extending to anterior level of ventral sucker. Collar well developed, with 45, stout, relatively short spines with short and sharply pointed tip; all collar spines of similar size, dorsal spines in double row. Collar spine arrangement: on each side four angle spines and six lateral spines, dorsal spines 25. Oral sucker ventro-subterminal, rounded, muscular. Ventral sucker rounded, muscular, post-equatorial, slightly larger than oral sucker, outer surface covered by inconspicuous tegumental fold bearing 2-3 rows of sharp-pointed tegumental spines; with an outer circle of six smaller papillae, and with an inner circle of four larger papillae (Fig. 7G). Prepharynx nearly as long as pharynx. Pharynx muscular, oval. Oesophageal primordium long; intestinal bifurcation just anterior to ventral sucker. Caecal primordia consist of single rows of cells with granular content, reach to posterior extremity of body. Cystogenous gland-cells numerous, rounded, with fine granular contents, extending from posterior level of pharynx to posterior extremity of body, most prominent laterally. Penetration gland-cells arranged on both sides of oesophageal primordium, of five pairs, ducts opening on dorsal lip of oral sucker, slightly stain with Neutral red. Genital anlagen consist of two oval, compact, interconnected groups of small transparent cells, anterodorsal and just posterior to ventral sucker. Excretory vesicle saccular, rounded (can enlarge up to width of ventral sucker), constricted anteriorly. Main collecting ducts ascending from constricted part of excretory vesicle, dilated between posterior level of pharynx and anterior level of ventral sucker, densely filled with numerous (c. 160) refractive excretory granules of similar size (for diameter see below), in most specimens simple, in some specimens 2-3 granules may fuse; ducts narrow and reflex at level of pharynx and lead backwards. Flame-cells arranged in triplets, flame-cell formula $2[3+3+(3+3+3)]=30$; numerous ciliary tufts in main channels, c. eight on each side. Excretory pore at junction of body and tail; caudal excretory duct bifurcates in c. the first fifth of tail length. Tail muscular, simple, of similar length as body when live; with blunt tip.

Measurements of formalin fixed cercariae (based on six specimens; not all specimens contributed a data point to all metrical variables): Body 346-384 × 109-127 (365 × 119). Collar $60-78 \times 80-102(72 \times 93)$. Oral sucker $43-47 \times$ 43-63 $(45 \times 51)$. Ventral sucker 44-59 × 45-61 $(52 \times 53)$. Sucker width ratio 1:0.97-1.13 (1:1.05). Prepharynx 19-27 (21) long. Pharynx 18-22 × 19-25 $(20 \times 21)$. Collar spines: angle spines 9-11 (10) long, lateral spines 10-12 (11), dorsal spines 8-11 (9). Tegumental spines 2-3 (3) long. Diameter of excretory granules $3-4$ (3). Tail $359 \times 27$. TL/BL ratio 0.96 .

Rediae (Fig. 5K)

(Measurements of live daughter-rediae, based on 10 specimens): Body elongate, orange-yellowish, 828-1908 × 105-141 $(1242 \times 119)$. Collar well pronounced, entire. Birth pore just behind collar. Two prominent locomotory appendages present postequatorially (i.e. in third quarter of body length), 34-56 (41) long. Pharynx rounded, muscular, 53-70 × 46-63 $(63 \times 55)$. Intestine sac-like, with red-brownish contents, in c. first quarter of body.

Remarks: The present cercariae agree well in their morphology with Echinoparyphium in the characters as mentioned above [73]. The present species is genetically close to E. mordwilkoi, based on sequences provided by Stanevičiūtè et al. [123]; however, they were without morphological 
documentation. Also, in morphology, the present cercariae are similar to E. mordwilkoi which was characterised morphologically by Grabda-Kazubska \& Kiseliene [54] ex Valvata piscinalis (O. F. Müller) in Lithuania (Lake Asveja). The dimensions of the cercariae overlap; however, the present cercariae differ in possessing clearly visible tegumental spines on the surface of the ventral sucker (Figs. 7E and 7G); also the ventral posterior extent of the tegumental spines is different (reaching the posterior level of the ventral sucker vs. to the half distance between the ventral sucker and posterior body extremity). Echinostome cercariae were reported from $V$. piscinalis in Great Britain by Harper [58] and McCarthy [93] as Echinoparyphium recurvatum which was revealed as a species complex [93], thus the identity of these records is unclear. Wesenberg-Lund [137] reported echinostome cercariae as Cercaria abyssicola Wesenberg-Lund, 1934 from $V$. piscinalis from Tjustrup Lake in Denmark; and Zdun [141] recorded $C$. abyssicola in $V$. piscinalis from the river Tisa in Ukraine. Also, Kiseliene et al. [72] recorded C. abyssicola ex $V$. piscinalis from Lake Asveja, Lithuania; however, they described the cercariae with a long fin-fold on tail, indicating that it belongs to a genus other than Echinoparyphium. The present cercariae are a species new to science and thus we confirm the diversity within the members of the genus Echinoparyphium, and the necessity to combine morphological and genetic data for accurate species delimitation.

\section{Echinoparyphium sp. 2}

First intermediate host: Physa acuta Draparnaud (Gastropoda: Physidae).

Locality: pond at Nordic House, Iceland.

Representative DNA sequences: MZ404663-MZ404665 (nad1); MZ409808 (28S).

Cercaria (Figs. 5L-5N, 7H-7J)

(Description and measurements based on live material of three specimens): Body elongate-oval, 312-347 × 203-232 $(329 \times 217)$, with maximum width just anterior to ventral sucker. Tegument thick, armed with robust, triangular, quite long, sharply pointed tegumental spines, those posterior to collar 3-5 (4) long; more slender and sharply pointed dorsally, becoming smaller and more slender posteriorly, particularly minute posterior to ventral sucker; ventrally extending from behind the collar up to posterior extremity, dorsally extending to forebody. Collar well developed, $60-79 \times 108-117$ $(69 \times 113)$, with 45 , relatively slender, sharply pointed collar spines. Collar spine arrangement: on each side four angle spines 12-15 (14) long; 37 marginal spines in double row; lateral spines 12-13 (13) long; dorsal aboral spines 13-14 (14) long; dorsal oral spines 12-14 (13) long, of similar length as aboral spines but more slender. Oral sucker ventro-subterminal, rounded, muscular, 45-52 × 59-63 $(48 \times 61)$. Ventral sucker rounded to transversely-oval, muscular, postequatorial, surrounded by inconspicuous radial tegumental fold, with a circle of six papillae, 59-69 × 78-85 $(63 \times 81)$; larger than oral sucker; sucker width ratio 1:1.25-1.44 (1:1.33). Prepharynx distinct, narrow, 13-20 (17) long, up to length of pharynx. Pharynx oval to elongate-oval, muscular, 23-24 × 19-24. Oesophageal primordium long; intestinal bifurcation anterior to ventral sucker. Caecal primordia reach to posterior body extremity. Cystogenous gland-cells numerous, with fine granular contents, extending from posterior level of pharynx to posterior extremity of body. Penetration gland-cells indistinct, around oesophageal primordium, number could not be determined, inconspicuous outlets on dorsal lip of oral sucker. Genital anlagen consist of two compact, interconnected, transparent groups of small cells, located median, anterodorsal and posterior to ventral sucker. Excretory vesicle saccular, rounded, constricted anteriorly. Main collecting ducts ascending from constricted part of excretory vesicle, ducts dilated between level of pharynx and anterior level of ventral sucker, densely filled with c. 100-216 small refractive excretory granules of similar size, in most specimens simple, in some specimens 2-3 granules may fuse, diameter 3-5 (4), becoming smaller only anteriorly and posteriorly; ducts narrow and reflex at level of pharynx and lead backwards. Flame-cell formula not determined. Excretory pore at junction of body and tail; caudal excretory duct bifurcates at c. first quarter of tail length into two oblique branches opening laterally. Tail simple, devoid of fin-folds, longer than body when live, muscular, contractile, with bluntly pointed tip.

Measurements of cercariae fixed in ethanol (based on 30 specimens; not all specimens contributed a data point to all metrical variables): Body 304-396 $\times$ 127-180 $(340 \times 151)$. Collar $62-92 \times 82-110(75 \times 96)$. Oral sucker $37-58 \times 39-54(48 \times 47)$. Ventral sucker 40-71 × 48-74 $(57 \times 64)$. Sucker width ratio 1:1.04-1.69 (1:1.36). Prepharynx 8-22 (15) long. Pharynx 20-35 × 15-25 (26 × 19). Collar spines: angle spines 12-14 (13) long; lateral spines 11-13 (12); dorsal oral spines 11-12 (11); dorsal aboral spines 11-13 (12) long. Diameter of excretory granules usually 3-5 (4), in some specimens with fused granules, diameter up to 9. Tail $337-481 \times 40-57(440 \times 48)$. TL/BL ratio $0.93-1.57$ (1.31).

\section{Redia (Fig. 5O)}

(Measurements of live daughter-rediae, based on two specimens): Body stout, orange-brownish, with tapered anterior extremity, blunt posterior extremity, 1293-1727 × 371-373. Collar well developed, narrower than body, 163-233 wide. Birth pore just behind collar. Two locomotory appendages present at mid-level of body, 62 long. Pharynx small, rounded, muscular, 49-52 × 49-50. Intestine short, in c. first fifth of body, sac-like.

Remarks: The present cercariae agree in their morphology with those of the genus Echinoparyphium in characters stated above [62, 73], only in some specimens larger excretory granules were noticed (with a diameter up to $9 \mu \mathrm{m}$ ). Our new sequences for nad 1 are highly similar to sequences deposited in GenBank by Gordy and Hanington [51] and identified as Echinoparyphium sp. A (MH369158 and MH369047), and Hypoderaeum sp. Lineage 2 (MH369080), all from Physa gyrina in Alberta, Canada. Alas, the same sequences were identified under different names by Gordy \& Hanington [51], therefore, to avoid further confusion, we chose to name our species Echinoparyphium sp. 2. The present cercariae were found in one single locality in Iceland (Nordic House, Vatnsmýri bird reserve, Reykjavík), a popular area for nesting birds and with an established population of $P$. acuta, an invasive snail originating from North America [91], dwelling in Iceland for more than 
40 years (Skírnisson \& Schleich, unpublished). We had been finding Echinoparyphium sp. 2 consistently for the last two years in snails, indicating that the trematode's circulation in the environment is well established. The relation to the North American trematodes recorded by Gordy \& Hanington [51] underlines the link of the Icelandic fauna to that of North America presupposed by the occurrence of suitable intermediate hosts (introduced $P$. acuta) and migratory bird hosts nesting in north Canada and stopping or wintering in Iceland [125].

\section{Echinostoma Rudolphi, 1809}

\section{Echinostoma nasincovae Faltýnková, Georgieva, \\ Soldánová \& Kostadinova, 2015}

First intermediate host: Planorbarius corneus (Linnaeus) (Gastropoda: Planorbidae).

Locality: Lough Corrib, Ireland.

Representative DNA sequences: MZ404666 (nad1); MZ409809 (28S).

Remarks: Cercariae of Ec. nasincovae are among the most common in Europe [32, 35] in P. corneus; for a long time, they had been reported under the name Cercaria spinifera La Valette, 1855 or Echinostoma spiniferum [98, 99]. The natural definitive host is still unknown, and the life-cycle had been elucidated using birds (Gallus gallus $f$. dom., Anas platyrhynchos f. dom.) and mammals (Mesocricetus auratus) as experimental hosts by Našincová [99] (see [32]). The species is a new record for Ireland, indicating its wide distribution also in the western part of Europe.

\section{Echinostoma revolutum (Frölich, 1802) Rudolphi, 1809 sensu stricto}

First intermediate host: Radix balthica (Linnaeus) (Gastropoda: Lymnaeidae).

Locality: pond at Nordic House, Iceland.

Representative DNA sequences: MZ404667-MZ404672 (nad1); MZ409810 (28S).

Remarks: Cercariae of Echinostoma revolutum s. str. have been occurring regularly in $R$. balthica in Iceland [46, 48], see Table 1); the species is common in Central Europe in different first intermediate hosts ( $R$. auricularia, $R$. balthica, L. stagnalis, and S. palustris; [31, 46, 48]). Georgieva et al. [46] found Ec. revolutum in tufted duck Aythia fuligula; these and other ducks are also common in Iceland, thus ensuring the circulation of the life-cycle stages there. The species is the type-species of the so called "revolutum" group, the systematics of which had long been controversial, and which was resolved by Georgieva et al. [46] and Faltýnková et al. [32] in Europe as the species sensu stricto, and the species from North America was revealed as a closely related species, which still awaits description as a new species (see below).

\section{Echinostoma revolutum (Frölich, 1802) Rudolphi, 1809 of Detwiler et al. [24]}

First intermediate hosts: Radix auricularia (Linnaeus), Stagnicola elodes (Say) (Gastropoda: Lymnaeidae).

Localities: Fairbanks, small lake near airport, Tanana, pool on river bank, Alaska, USA.

Representative DNA sequences: MZ404673-MZ404675 (nad1); MZ409811 (28S).
Cercaria (Figs. 6A-6D, 9A-9B)

(Description based on live material and 11 fixed specimens): Body oval to elongate-oval, muscular, with maximum width just anterior to ventral sucker. Tegument thick, armed with triangular spines, becoming smaller and less dense posteriorly; ventrally reaching up to posterior level of ventral sucker, dorsally reaching to anterior level of ventral sucker. Collar well developed, with 37 , long, robust collar spines with sharply pointed tips, all of similar size (Fig. 6D). Collar spine arrangement: on each side five angle spines and six lateral spines in single row; 15 dorsal spines in double row. Oral sucker subterminal, muscular, rounded. Ventral sucker rounded, muscular, just postequatorial, larger than oral sucker. Prepharynx distinct, shorter than pharynx. Pharynx elongate-oval, muscular. Oesophageal primordium long; intestinal bifurcation at level of first quarter of ventral sucker. Caecal primordia reach to posterior body extremity. Cystogenous gland-cells numerous, with fine granular contents, occupy most of body posterior to pharynx. Penetration gland-cells indistinct, around oesophageal primordium, covered by cystogenous gland-cells; their duct openings present on dorsal lip of oral sucker. Paraoesophageal gland-cells few (probably 4-5 pairs, exact number could not be determined), located on both sides of oesophagus, with long ducts, outlets surrounding oral sucker. Genital anlagen consist of two compact, interconnected, transparent groups of small cells, located median, anterodorsal and posterior to ventral sucker. Excretory vesicle saccular, constricted anteriorly. Main collecting ducts ascending from constricted part of excretory vesicle, dilated between posterior level of pharynx and anterior margin of ventral sucker, contain c. 30-40 simple or double refractive excretory granules of different size, largest at midlevel of ducts (for diameter see below); ducts narrow and reflex at level of prepharynx and lead backwards. Flame-cell formula not determined. Excretory pore at junction of body and tail. Caudal excretory duct bifurcates in c. first quarter to first fifth of tail length into two oblique branches opening laterally. Tail muscular, contractile, longer than body when fixed; tip forms highly contractile slender process (nearly $1 / 5$ of tail length). Seven well-pronounced tegumental fin-folds present on tail: two dorsal, three ventral and two ventro-lateral (Figs. 6B and 9B). Distal dorsal and ventral fin-folds most prominent, distal dorsal fin-fold longer than ventral one; distal ventral fin-fold connected with proximal ventral fin-fold by narrow tegumental elevation; proximal dorsal fin-fold longest; ventro-lateral finfolds short; smallest (but prominent) ventral fin-fold located near base of tip of tail.

Measurements of cercariae fixed in cold formalin (based on 11 specimens; not all specimens contributed a data point to all metrical variables): Body 185-239 × 123-150 $(210 \times 136)$. Oral sucker $42-51 \times 41-48(46 \times 46)$. Ventral sucker 44 $64 \times 56-69(56 \times 64)$. Sucker width ratio 1:1.21-1.50 (1:1.40). Prepharynx 2-5 (4) long. Pharynx 13-23 × 11-18 $(18 \times 15)$. Collar spines: angle spines 9-14 (12) long; lateral spines 9-14 (12); dorsal spines 10-14 (12). Tegumental spines 2-3 (2) long. Diameter of excretory granules 3-7 (5). Tail 345$439 \times 36-48(405 \times 43) . \mathrm{TL} / \mathrm{BL}=1.65-2.17(1.93)$.

Redia (Fig. 6E)

(Description and measurements of daughter-rediae fixed in cold formalin, based on 11 specimens, not all specimens 


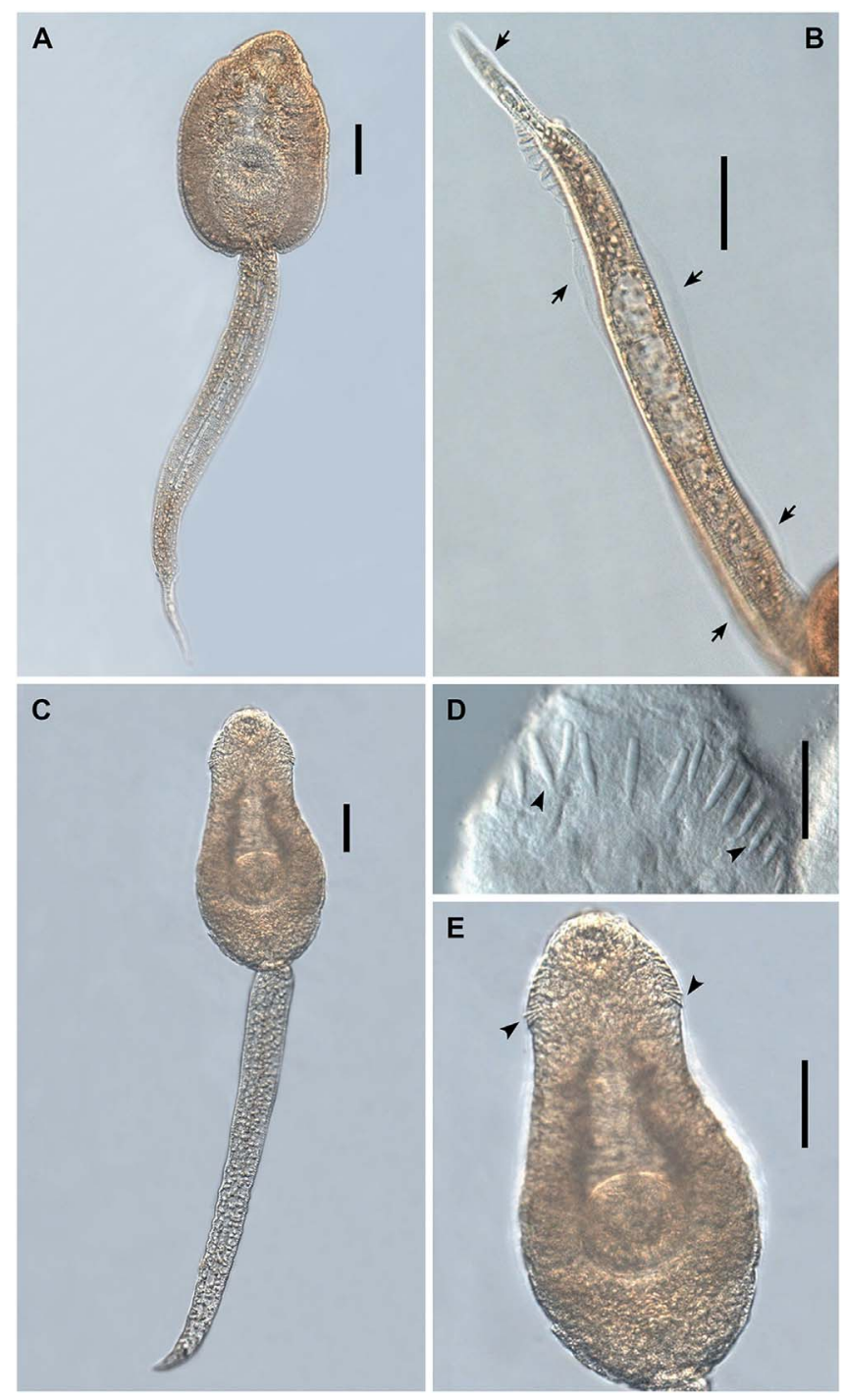

Figure 9. Photomicrographs of live cercariae of Echinostoma revolutum ex Radix auricularia. (A) body and tail, ventral view, (B) tail showing fin-folds (arrows), lateral view. Fixed cercariae of Echinostomatidae gen. sp. ex Lymnaea stagnalis. (C) body and tail, ventral view, (D) head collar, dorsal view, showing dorsal collar spines (arrowheads), (E) body, showing angle collar spines (arrowheads), ventral view. Scale-bars: A, B, E, $50 \mu \mathrm{m}$; C, $100 \mu \mathrm{m}$; D, $20 \mu \mathrm{m}$.

contributed a data point to all metrical variables): Body brownish-orange, long, stout, 1674-3001 × 266-381 $(2202 \times$ 302). Collar well pronounced, entire, 125-152 (138) wide, narrower than body. Birth pore just posterior to collar. Two prominent locomotory appendages present in second half of body, 65-79 (71) long. Pharynx rounded, muscular, 55$61 \times 49-55(58 \times 52)$. Intestine short, sac-like, with reddish contents, reaching not far behind collar.

Remarks: The morphology of the present cercariae agrees well with those of the genus Echinostoma in the presence of 37 collar spines (five angle spines, dorsal spines in double row), a tail bearing seven fin-folds, and not too numerous (less than 50) excretory granules of differing size (largest ones up to $7 \mu \mathrm{m})[32,34,73]$. The specimens described here belong to the lineage of Ec. revolutum as defined by Georgieva et al. [48]. The isolates recorded previously from North America by Detwiler et al. [24, 25] were shown by Georgieva et al. [48] to represent another (cryptic) species of the "revolutum" complex, i.e. Ec. revolutum and forming a sister clade to Ec. revolutum s. str. [48]. Morphologically, the present cercariae look similar to Echinostoma revolutum s. str. ex L. stagnalis from Europe in the presence of paraoesophageal gland cells with long ducts and also in the dimensions of the cercariae, which are similar. However, the cercariae differ in the arrangement of fin-folds on tail, which is similar to Ec. paraulum (another species belonging to the "revolutum" complex; [32]) in the connection of the ventral proximal and distal fin-folds by a small tegumental ridge. In North America, Beaver [5] described in detail cercariae of Echinostoma revolutum; however, they possess a larger and more slender body $(323 \times 95 \mu \mathrm{m})$, when fixed, and a slightly longer tail $(450 \mu \mathrm{m})$ than cercariae in our samples. Also, the body spination is different, Beaver [5] stated that the whole body is spined ventrally and almost all dorsally (vs. spines reaching the posterior level of the ventral sucker ventrally and the anterior level of the ventral sucker dorsally in our material).

The present cercariae constitute a separate lineage, differing genetically and morphologically from Ec. revolutum s. str.; however, a description of the species awaits the discovery of adults. They use more than one lymnaeid snail species as first intermediate hosts, i.e. S. elodes widely distributed in USA and Canada [15], and $R$. auricularia which was introduced from Europe to North America [15, 133]. Moreover, because of the cryptic nature of the species of Echinostoma, further investigations on the diversity of Echinostoma based on integrative taxonomy will help to better evaluate the host-use and geographical distribution of Echinostoma in America.

\section{Echinostoma sp. IG sensu Georgieva et al. (2013)}

First intermediate hosts: Radix balthica (Linnaeus), Myxas glutinosa (O.F. Müller) (Gastropoda: Lymnaeidae).

Localities: Lake Ashildarholtsvatn, pond at Nordic House, Iceland; Lough Corrib, Ireland.

Representative DNA sequences: MZ404676-MZ404678 (nad1); MZ409812, MZ409812 (28S).

Remarks: The morphology of our new material from Iceland and Ireland corresponds well to Echinostoma sp. IG described by Georgieva et al. [48]. Echinostoma sp. IG was previously found in Iceland (in $R$. balthica), Germany (R. auricularia) and Great Britain (in Planorbis sp.) [48]; it is a new record for Ireland, indicating that this species is common in the European North Atlantic region as it is most probably circulating with aquatic birds nesting in Iceland and wintering in Ireland, Great Britain and continental Europe, moreover, the snail species used as first intermediate hosts are commonly distributed in Europe, while R. balthica is also distributed in Siberia and Central Asia [133].

\section{Hypoderaeum Dietz, 1909}

\section{Hypoderaeum conoideum (Bloch, 1782) Dietz, 1909}

First intermediate host: Lymnaea stagnalis (Linnaeus) (Gastropoda: Lymnaeidae).

Locality: Huumonjärvi, Finland.

Representative DNA sequences: MZ404679-MZ404682 (nad1); MZ409814 (28S). 

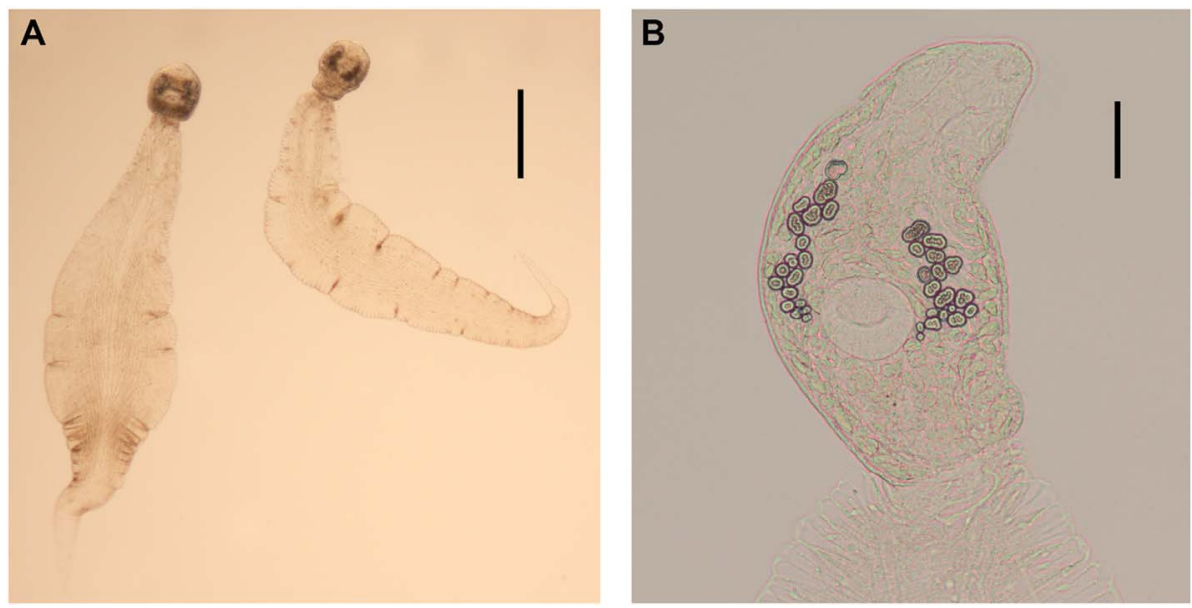

Figure 10. Photomicrographs of live cercariae of Neopetasiger sp. 5 ex Planorbis planorbis. (A) body and tail, ventral view, (B) body, ventral view. Scale-bars: A, $200 \mu \mathrm{m} ; \mathrm{B}, 50 \mu \mathrm{m}$.

Remarks: The new material from Finland keys down to Hypoderaeum conoideum of Faltýnková et al. [34]. The nad1 sequences of this species showed low intraspecific divergence to the sequences of $H$. conoideum published by Kostadinova et al. [76] and Miquel et al. [95]. The 28S sequences of the present study were identical to those obtained from adults of $H$. conoideum in the USA and Ukraine published by Tkach et al. [126]. In the past, $H$. conoideum was reported also from Iceland by Blair [7] who found metacercariae in Radix peregra (syn. of $R$. balthica) and obtained adults experimentally which he identified as $H$. conoideum. In Europe, $H$. conoideum is a frequent parasite of anseriform birds, and as first intermediate hosts, common snail species were recorded, i.e. L. stagnalis, Radix peregra and $R$. peregra ovata (synonyms of $R$. balthica) and S. palustris [119].

\section{Moliniella Hübner, 1939}

\section{Moliniella anceps (Molin, 1859) Hübner, 1939}

First intermediate host: Stagnicola fuscus (C. Pfeiffer) (Gastropoda: Lymnaeidae).

Locality: Lough Mask, Ireland.

Representative DNA sequences: MZ404683 (nad1); MZ409815 (28S).

Remarks: The new material from Ireland corresponds well in morphology to $M$. anceps as in the key of Faltýnková et al. [34]. The only sequence (28S) of $M$. anceps available in GenBank was provided by Tkach et al. [126] of a metacercaria ex $P$. corneus in Lithuania. This one and our $28 S$ sequences were identical. Cercariae of this species were found not to be too common in Stagnicola corvus and L. stagnalis in central Europe; however, metacercariae are quite common [34]. The present study provides the first nad 1 sequence for $M$. anceps and the first record of this species in Ireland, which is the westernmost distribution of the species.

\section{Neopetasiger Bashkirova, 1941}

\section{Neopetasiger islandicus Kostadinova \& Skírnisson, 2007}

First intermediate host: Gyraulus cf. parvus (Say) (Gastropoda: Planorbidae).
Localities: lakes Ashildarholtsvatn and Mývatn, Iceland. Representative DNA sequences: MZ404684-MZ404686 (nad1); MZ409816 (28S).

Remarks: The morphology of the present species corresponds well to that described by Georgieva et al. [47]. The adults of Neopetasiger islandicus were first described by Kostadinova \& Skírnisson [77] from the horned grebe Podiceps auritus in Mývatn, Iceland. The other life-cycle stages were described by Georgieva et al. [47] ex Gyraulus cf. laevis and the three-spined stickleback, Gasterosteus aculeatus, respectively, from Lake Mývatn in Iceland. Since we have material of $N$. islandicus from the type-locality, we assume the correct identification of the snail host is G. cf. parvus, which is a species widely distributed in North America, and which was also found in south Greenland; currently it is spreading in Europe [50, 90, 135]. Adults and cercariae of $N$. islandicus were also found in North America in the western grebe Aechmophorus occidentalis (Lawrence, 1858), and the snail Planorbula armigera (Say, 1821), respectively [52, 126], indicating that the species is not restricted to Iceland, and it can be expected to occur throughout North America, as A. occidentalis occurs from British Columbia to California [30], and the snail G. parvus is common [15].

\section{Neopetasiger sp. 5}

First intermediate host: Planorbis planorbis (Linnaeus) (Gastropoda: Planorbidae).

Locality: Lough Corrib, Ireland.

Representative DNA sequences: MZ404687 (nad1); MZ409817 (28S).

Cercariae (Figs. 6F-6H, 10A-10B)

(Description and measurements based on two live specimens): Body small, elongate-oval, dark, 195-203 long, with maximum width at level of ventral sucker, 114-121. Tegument thick, armed with minute spines embedded in tegument. Collar narrower than body, 47-67 × 80-97, well developed, with 19 , robust, bluntly pointed collar spines. Collar spine arrangement: on each side four angle spines (14 long); two lateral spines on each side; seven dorsal spines (13-17 (14) long) in single row (see Fig. 6H). Oral sucker ventro-subterminal, rounded, muscular, $41-47 \times 41-47$. Ventral sucker rounded to 
transversely-oval, muscular, postequatorial, slightly larger than oral sucker, 51-52 × 52-61; sucker width ratio 1:1.12-1.47. Prepharynx distinct, narrow, of similar length as pharynx, 20-21 long; pharynx elongate-oval to oval, 18-24 × 18-22. Oesophageal primordium long; intestinal bifurcation anterior to ventral sucker. Caecal primordia narrow, reach to excretory vesicle. Cystogenous gland-cells numerous, with rhabditiform contents; extending from posterior level of pharynx to posterior extremity of body, most prominent in two lateral and one median row. Penetration gland-cells indistinct, around oesophageal primordium, number could not be determined. Genital anlagen consist of two interconnected transparent groups of small cells, anterodorsal and posterior to ventral sucker. Excretory vesicle bipartite, rounded at base; continues in anterior narrowed tail region as accessory excretory vesicle c. 22-29 long. Main ascending collecting ducts dilated between posterior level of pharynx and mid-level of ventral sucker, contain 18-29 large refractive excretory granules, formed by fusion of 2-4 smaller ones, granules of irregular shape, becoming smaller posteriorly, diameter 5-18; ducts narrow and reflex at level of prepharynx and lead backwards. Tail leaf-like (TL/TW ratio $=3.57-4.82$ ), with strong musculature, almost transparent, with only few pigment, 1112-1122 long, much longer than body (TL/BL ratio $5.48-5.75$ ), with maximum width at $\mathrm{c}$. its mid-length, 231-314 wide.

Measurements of cercariae fixed in ethanol (based on 10 specimens): Body $223-243 \times 104-118(236 \times 110)$. Collar $43-58 \times 46-78(52 \times 67)$. Oral sucker $37-43 \times 39-45$ $(40 \times 43)$. Ventral sucker 44-62 × 47-56 $(50 \times 51)$. Sucker width ratio 1:1.09-1.35 (1:1.20). Collar spines: angle spines 13-15 (14) long; lateral spines 13-14 long. Diameter of excretory granules 4-16 (11). Tail 311-717 (536) long, strongly contracted when fixed, maximum width 97-240 (185), TL/TW ratio 2-4 (3); longer than body, TL/BL ratio 1.35-3.03.

Remarks: The morphology of the present cercariae corresponds well to that of the genus Neopetasiger in possessing a large, conspicuous tail, much longer than body, a total of 19 collar spines with four angle spines on each side, cystogenous gland-cells with rhabditiform contents and large composite excretory granules in main ascending excretory channels $[118,126]$. In the keys of Kostadinova \& Chipev [74] and Selbach et al. [118], the present cercaria keys down to Cercaria tidfordensis Nasir, 1962 ex Planorbis carinatus O.F. Müller in the presence of 19 collar spines, of a colourless body and tail, and a leaf-shaped tail, which is relatively short (311-717 $\mu \mathrm{m}$ vs. 540-740 $\mu \mathrm{m}$; TL/TW ratio 2-4 vs. 3-4). However, the TL/BL ratio for fixed cercariae in our material is lower than in Kostadinova \& Chipev [74] (TL/BL ratio 1.35-3.03 vs. 3.5-4.0). With the leaf-shaped tail, its most typical feature, our cercariae are similar to $N$. islandicus; however, the tail is shorter compared to $N$. islandicus (311-717 $\mu \mathrm{m}$ vs. 740 $970 \mu \mathrm{m}$ ) and wider (TL/TW 2-4 vs. 4-8) and our cercariae possess less pigment, i.e. there is no yellow pigment in the body (vs. N. islandicus). Another leaf-shaped cercaria, Cercaria thamesensis of Khan [71] was described with 20 collar spines, and its tail is longer (TL/TW 4-9) than in our cercariae; therefore, it cannot be assigned to our material. Apparently, the diversity of Neopetasiger with cercariae with leaf-like tails is greater than is so far known and enlarges the number of yet provisionally-named species from snails to five (see Selbach et al. [118] for Neopetasiger sp. 1-4); however, a reliable description of a new species awaits the discovery of corresponding adults which most likely parasitise grebes.

\section{Echinostomatidae gen. sp.}

First intermediate host: Lymnaea stagnalis (Linnaeus) (Gastropoda: Lymnaeidae).

Locality: Huumonjärvi, Finland.

Representative DNA sequences: MZ404688, MZ404689 (nad1); MZ409818, MZ409819 (28S).

Cercaria (Figs. 6I-6K, 9C-9E)

(Description and measurements based on live material and 24 fixed cercariae): Body elongate-oval, with maximum width at level of ventral sucker. Tegument thick, armed with stout, triangular tegumental spines, not too dense, becoming smaller posteriorly; ventrally extending to mid-level of ventral sucker, dorsally extending to forebody. Collar well developed, with 27, long, slender sharply pointed collar spines. Collar spine arrangement: on each side four angle spines; four lateral spines in single row on each side; 11 dorsal spines with three aboral spines in centre and two smaller oral spines on each side, other dorsal spines aboral, in one row (see Figs. 6K and 9D). Oral sucker ventro-subterminal, rounded, muscular. Ventral sucker rounded, muscular, postequatorial, larger than oral sucker. Rim of both suckers surrounded by inconspicuous tegumental fold. Prepharynx distinct, narrow, nearly as long as pharynx. Pharynx oval, muscular. Oesophageal primordium long; intestinal bifurcation at level of anterior edge of ventral sucker. Caecal primordia reach to posterior body extremity. Cystogenous gland-cells numerous, with fine granular contents, extending from posterior level of pharynx to posterior extremity of body. Penetration gland-cells indistinct, around oesophageal primordium, number could not be determined. Genital anlagen consist of two compact, interconnected, transparent groups of small cells, located median, anterodorsal and posterior to ventral sucker. Excretory vesicle saccular, rounded, constricted anteriorly. Main collecting ducts ascending from constricted part of excretory vesicle, ducts dilated between level of pharynx and anterior level of ventral sucker, densely filled with 140-170 refractive excretory granules being largest in mid-part and becoming smaller anteriorly and posteriorly (for diameter see below); ducts narrow and reflex at level of pharynx and lead backwards. Flame-cell formula not determined. Excretory pore at junction of body and tail; caudal excretory duct bifurcates in c. first quarter of tail length into two oblique branches opening laterally. Tail simple, devoid of fin-folds, much longer than body when fixed, muscular, contractile, with bluntly pointed tip.

Measurements of formalin fixed cercariae (based on 10 specimens; not all specimens contributed a data point to all metrical variables): Body 267-379 × 125-157 $(326 \times 142)$. Collar 63-80 × 76-92 $(69 \times 85)$. Oral sucker 45-53 × 41$47(50 \times 44)$. Ventral sucker $49-61 \times 55-59(54 \times 57)$. Sucker width ratio 1:1.21-1.41 (1:1.29). Prepharynx 6-19 (12) long. Pharynx 19-25 × 13-21 $(22 \times 16)$. Collar spines: angle spine 14 long; lateral spines 12-13 long; larger dorsal aboral spines 11-14 long; small dorsal oral spines 9-10. Tail 337$490 \times 34-51(440 \times 44)$. TL/BL ratio 0.98-1.62 (1.37). 
Measurements of ethanol fixed cercariae (based on 14 specimens; not all specimens contributed a data point to all metrical variables): Body $238-272 \times 100-136(254 \times 118)$. Collar 51$86 \times 57-83(60 \times 68)$. Oral sucker $35-48 \times 36-48(42 \times 42)$. Ventral sucker $40-58 \times 42-64(48 \times 52)$. Sucker width ratio 1:0.98-1.50 (1:1.26). Prepharynx 9-16 (13) long. Pharynx $15-22 \times 11-18(19 \times 14)$. Diameter of excretory granules 3-6 (4). Collar spines: angle spines 8-14 (11) long; lateral spines 8- 14 (12) long; larger dorsal aboral spines 10-16 (13) long; smaller dorsal oral spines 8-12 (10) long. Tegumental spines posterior to collar 1-2 long. Diameter of excretory granules 3-6 (4). Tail $361-458 \times 34-45(409 \times 39)$. TL/BL ratio $1.48-1.88$ (1.61).

Remarks: The present cercariae fall within the family Echinostomatidae in the presence of typical features stated above and in Kostadinova [73]. However, based on the combination of its characters, i.e. 27 slender collar spines, excretory granules of mid-size (up to $6 \mu \mathrm{m}$, similar to Echinostoma) and quite numerous (140-170 $\mu \mathrm{m}$, typical for Echinoparyphium), we could not assign the present cercariae to any of the known genera of the family Echinostomatidae. The other genera with similar species bearing 27 collar spines are Isthmiophora, Petasiger (the former Paryphostomum), and Drepanocephalus; however, their cercariae have differently arranged collar spines (no smaller dorsal oral spines), suckers provided with a well-pronounced circular fin-fold and much larger and less numerous excretory granules. For the other known genera with species with 27 collar spines [73], such as Bashkirovitrema, Chaunocephalus and Balfouria, their cercariae are not documented, neither are they genetically sequenced. Although sequences of adult Chaunocephalus are available (Table 4), our isolate clustered in a distant clade from a clade with C. ferox (Rudolphi, 1795) (Fig. 4). Apart from the specific arrangement of the collar spines, which most resembles Isthmiophora, the excretory granules in our cercariae are similar to those of the genus Echinostoma, i.e. they are of a similar size and they are larger at the mid-level of the channels; however, they are more numerous and they are filling the channels as densely as in Echinoparyphium.

Although the morphology of the present cercariae is quite characteristic (smaller dorsal oral spines and excretory ducts densely filled with excretory granules larger than in Echinoparyphium), it is difficult to find a description precise enough for comparison. Our cercariae are most similar to those described by Ginetsinskaya \& Dobrovolskiy [49] as Cercaria helvetica XXI Dubois, 1929 ex Radix auricularia, R. ovata, and $R$. peregra from Astrakhan, Russia, with 27 collar spines (however, with no precise information on collar spine arrangement) and main ducts filled with numerous small granules, with bigger ones in the middle. The dimensions of body (267$379 \times 125-157 \mu \mathrm{m}$ vs. $270-330 \times 150-190 \mu \mathrm{m})$ in our material fixed in formalin are similar; however, the tail length (361-458 $\mu \mathrm{m}$ vs. $480-570 \mu \mathrm{m})$ and suckers in our cercariae are smaller (oral sucker $35-48 \times 36-48 \mu \mathrm{m}$ vs. diameter 50-70 $\mu \mathrm{m}$; ventral sucker $40-58 \times 42-64 \mu \mathrm{m}$ vs. diameter $60-80 \mu \mathrm{m})$. Another similar cercaria described by Ginetsinskaya \& Dobrovolskiy [49] ex L. stagnalis is Cercaria astrakhanica VI with 27 collar spines and larger excretory granules; however, these cercariae were much larger (body $410-550 \mu \mathrm{m}$ ) than those in our material. Since no further information on the collar spines is available and the drawings of excretory granules are quite schematic, it is impossible to say if the present cercariae could be identical with those described. Ginetsinskaya \& Dobrovolskiy [49] recorded two more cercariae (Cercaria astrakhanica $\mathrm{V}$ and Cercaria coronata Kotova, 1939) with 27 collar spines, however with a differing size and number of excretory granules and with different metrical characteristics.

Another unidentified echinostome cercaria was described by Odening [104] as bearing usually 29 (sometimes 27-31) collar spines, from L. stagnalis in Germany and as occurring very rarely. The body length of these cercariae (257-294 $\mu \mathrm{m})$ overlaps with that of our material, the tail (length 580-694 $\mu \mathrm{m}$ ) however, is longer. Cercariae with the same morphology as in the present material were found in the Czech Republic before by one of the authors (AF, unpublished), indicating that these unidentified cercariae are likely a part of the European echinostome fauna; however, they are probably very rare. Only with further availability of molecular data involving more genera, can the systematic affiliation of this material be solved.

\section{Discussion}

Using an integrative taxonomic approach and existing DNA sequence libraries, our investigation of the diversity of echinostomes in snails at more northern latitudes reports the presence of 14 species. Despite the fact that the diversity of echinostomes is relatively well studied in Europe [32, 46], we discovered four species, namely, Echinoparyphium sp. 1, Echinoparyphium sp. 2, Neopetasiger sp. 5 and Echinostomatidae gen. sp. that appear to be novel in Europe and unique to Finland (Echinoparyphium sp. 1, Echinostomatidae gen. sp.), Iceland (Echinoparyphium sp. 2) and Ireland (Neopetasiger sp. 5). Our survey on echinostomes revealed records of two species in Alaska (USA), five species each in Finland and Iceland, and six species in Ireland. All species found in Ireland are new records for this country. The present study shows that there is some connection of the American trematode fauna with that from Europe (Eurasia) in Iceland, and the life-cycles of the trematodes are well established on the island, which is enabled by the presence of the snail intermediate hosts and the migration of birds within the East Atlantic flyway.

Our study adds new data on the geographical distribution for several species, some of them well-known. For four European species, E. aconiatum, E. recurvatum, Ec. nasincovae, and $M$. anceps described and reported in central, southern and eastern Europe, their distribution was found to extend to the most western part of Europe - Ireland. In Iceland, we found almost the same species spectrum as recorded in the past (see Table 1), with Echinoparyphium sp. 2 being a new record, and the presence of E. recurvatum was newly confirmed by genetic data from Iceland. Since Iceland lies on the East Atlantic flyway and is a nesting place for birds which overwinter on the British Isles, Norway or other parts [22], the trematode species are shared with continental Europe (E. recurvatum, Ec. revolutum s. str., Echinostoma sp. IG) and none are endemic to Iceland. Neopetasiger islandicus and Echinoparyphium sp. 2 using snails of American origin as first intermediate hosts are shared with the 
North American continent which could be explained by American birds using Iceland as a stopping or staging place when flying to/from their northern nesting places. The records of two known species, Ec. revolutum and E. rubrum found by us in Alaska (USA) together with the previous records based on DNA sequence data [24, 25, 51, 109, 126, 129], demonstrate that the geographical range of these species is wider than previously known, stretching between the northeast of the USA to the extreme northwest of the North American continent. The results of the phylogenetic analyses of Echinostoma spp. are consistent with those in previous studies [46, 48] and confirm the distribution of Ec. revolutum in North America and Ec. revolutum s. str. in Europe. These closely related species differ not only genetically, but also in morphology of their cercarial stages.

Two species in our material collected in Iceland, namely $N$. islandicus from Gyraulus cf. parvus and Echinoparyphium sp. 2 from Physa acuta were recorded in both Iceland and North America. Both snail host species are originally nonnative to Iceland. Gyraulus parvus is native to North America and is also known from Greenland; however, it has been reported to invade freshwaters in central and western Europe $[6,28,50,135]$, and from Iceland it was reported by MeierBrook [94]. While there are no data on its invasion pathway to Iceland, it is possible that it was introduced into the Icelandic freshwater ecosystems and later became a suitable host for North American trematodes brought with infected migratory birds. Although N. islandicus was described from an individual of horned grebe Po. auritus belonging to the isolated Icelandic population [77], this trematode species was recorded in a variety of bird hosts in the southern and northern states of the USA: in Po. auritus from Mississippi in 2004, and in the western grebe Aechmophorus occidentalis (Lawrence) and the rednecked grebe Podiceps grisegena (Boddaert) in North Dakota in 2005 and 2008, respectively ([126], unpublished data). According to Boulet et al. [12] and Kostadinova \& Skírnisson [77], the Icelandic population of Po. auritus is genetically distinct and strongly isolated geographically. Therefore, the species of $N$. islandicus was probably introduced to Iceland with its North American bird hosts.

The physid snail Physa acuta is native to North America and is currently considered an invasive species globally [28]; it is known to tolerate a wide range of environmental conditions, and it is a rapid coloniser as it can efficiently disperse via water, aquatic birds and mammals [86]. Due to its invasive nature, it has rapidly dispersed within southern and, more recently, in northern Europe [26]. In Iceland, it was introduced more than 40 years ago by spilling snail eggs from aquaria to a ditch in Reykjavík (Skírnisson \& Schleich, unpublished). Snails of $P$. acuta were a subject of previous parasitological studies in Iceland ([120], Skírnisson and Schleich, unpublished). However, to date they were not reported as hosts for any trematode intramolluscan stages (sporocysts or rediae), only metacercariae (echinostome and strigeid) encysted in the snails were found in 2007 in Iceland (Skírnisson and Schleich, unpublished). During our study, these snails were found in a single locality, a pond at Nordic House (Table 2) and after examination of almost 700 individuals, infection with cercariae of Echinoparyphium sp. 2 was found in 18.9\%. Apart from cercariae of Echinoparyphium sp. 2, the snails were also infected with echinostome and strigeid (of the genus Cotylurus) metacercariae. The relationships between trematodes and invertebrate second intermediate hosts are generally less specific [41] and, thus, it is not surprising that $P$. acuta serves as a second intermediate host for metacercariae and likely participates in transmission of the infection to the definitive bird hosts in Iceland. Prior to our study, in Europe P. acuta was reported as a host for cercariae from the "furcocercous" group in Spain [131] and cercariae of Fasciola hepatica L., 1758 in France [27]. However, both cases were not molecularly characterised. Our study reports the third record of $P$. acuta as a host for trematodes in Europe with supporting molecular and morphological evidence.

Two species of Neopetasiger were recorded in the present study. Neopetasiger islandicus was found parasitising Gyraulus cf. parvus in two localities in Iceland (Table 2). The previous records [47, 77] and our data demonstrate that the distribution of this species in Iceland is associated with the distribution of their definitive hosts - the population of horned grebe Po. auritus - but also with the distribution of the first intermediate host, i.e. G. cf. parvus [94]. The second species, Neopetasiger sp. 5 was recorded from Pl. planorbis in Lough Corrib in Ireland. Based on molecular and morphological analyses, this isolate did not match any of the previously described cercariae of Neopetasiger spp. in Europe or the genetic sequences published prior to our study. According to the most recent revision of the Echinostomatoidea [126], the genus Neopetasiger includes 14 valid species. Out of 14 species, five species have been described and reported in Europe: N. grandivesicularis (Ishii, 1935), N. islandicus, N. megacanthus (Kotlán, 1922), N. neocomense (Fuhrmann, 1927) and N. pungens (Linstow, 1894). Life cycles of N. grandivesicularis, $N$. islandicus and $N$. neocomense were elucidated and described including morphological descriptions of the larval stages [47, 68, 74]. Additionally, two latter species were molecularly characterised [47]. Therefore, cercariae of Neopetasiger sp. 5 may represent either $N$. megacanthus or $N$. pungens or a new, previously undescribed species. Our study brings the total number of molecularly characterised species within the genus Neopetasiger in Europe up to six, whereas, to date, adults of only five species are known. Thus, a higher diversity of Neopetasiger in Europe is reported and adults from bird definitive hosts are needed to definitively describe this diversity.

Two species of valve snails Valvata (Heterobranchia), $V$. macrostoma and $V$. piscinalis are known as first intermediate hosts for echinostomes in Europe, including four species of Echinoparyphium [37, 54, 58]. Previously, Valvata macrostoma was reported as a host for two unidentified species of Echinoparyphium in Finland [37], and V. piscinalis as a host for E. recurvatum in the UK [58] and E. mordwilkoi in Lithuania [54]. Thus far, only one record for E. mordwilkoi from $V$. piscinalis in Lithuania was confirmed by DNA sequences [123]. Here, based on combined genetic and morphological characterisation, we report Echinoparyphium sp. 1 from $V$. macrostoma in Finland, thus confirming the presence of another species of Echinoparyphium parasitising Valvata in Europe based on an integrative taxonomic approach. 
One of the most interesting findings of our study is the report of an echinostome species that most likely represents a member of a yet unknown genus of the Echinostomatidae. We could not assign Echinostomatidae gen. sp. to any currently known genus within the family based on morphological and molecular genetic analyses. Morphologically, it could potentially belong to Bashkirovitrema or Balfouria. However, members of neither genus have been reported in Europe thus far. Cercariae of Echinostomatidae gen. sp. show a combination of morphological characters similar to cercariae of Isthmiophora spp., Echinoparyphium spp. or Echinostoma spp. and they could be misidentified when based solely on analyses of cercarial morphology. This once again highlights the importance of DNA sequencing along with morphological characterisation for accurate species identification and evaluation of biodiversity.

Echinostomes have a wide range of first intermediate hosts which includes numerous species of freshwater pulmonate gastropods, with a few species (single species of Echinostoma, Echinoparyphium and Neoacanthoparyphium) parasitising snails belonging to former orthogastropods [126]. The present findings corroborate the intermediate host-use patterns found by Tkach et al. [126]. In the present study, echinostome cercariae were found in 11 species of snails from three families of pulmonate gastropods, Lymnaeidae, Physidae and Planorbidae, and one family of "lower Heterobranchia", Valvatidae. The number of echinostome species in different hosts did not vary greatly and ranged from one to three species. Only three echinostome species were shared between two snail species, E. recurvatum and Echinostoma sp. IG between $R$. balthica and M. glutinosa, and Ec. revolutum between $R$. auricularia and $S$. elodes. In a recent study on echinostomes from subSaharan Africa, Laidemitt et al. [84] recovered a high diversity of species which used a wide spectrum of snail hosts, some of their clades using even snails of different genera or families as first intermediate hosts. Compared to the situation near the equator, in the northern latitudes of the northern hemisphere, the spectrum of snail species used as hosts is less diverse, which is mainly connected to the generally lower diversity of free-living biota available as hosts in such regions [139]. Regardless of these differences in snail diversity, for echinostomes globally, it appears that they are a diverse group occurring in a wide range of snail species.

The majority of echinostomes exhibit stenoxenic specificity to their first intermediate hosts [126]. However, the molecular genetic analyses in the present study and in the previous study of Tkach et al. [129] demonstrated that E. rubrum is a euryxenous species and utilises snails from at least two families, namely Lymnaeidae (S. elodes, present study) and Planorbidae (Helisoma trivolvis [129]) as first intermediate hosts. Additionally, this species was reported from Physa spp. (Physidae [67]), albeit without DNA sequence confirmation. A more extensive assessment of the snail host range of echinostomes via integrative taxonomy will possibly lead to more discoveries of trematode specificity and transmission pathways, further helping to reveal ecological patterns in these host-parasite interactions.

Out of 12 species of echinostomes found in Europe during this study, four species were reported for the first time, showing that the diversity of these trematodes still remains unsatisfactorily sampled. The position of the species within the phylogenetic tree corresponded to that presented by Tkach et al. [126]; Hypoderaeum fell within the clade of Echinoparyphium, and the position of E. aconiatum still indicates its possible position as a separate genus [126], a state which needs further investigation. Laidemitt et al. [84] in their study on echinostome trematodes from African snails, recorded the same genera (Echinoparyphium, Echinostoma, Isthmiophora, Patagifer, Petasiger, and Ribeiroia) as in the northern hemisphere; however, they contained different species spectra. At the same time, there are few previous studies reporting echinostome species distributions to span the globe, all of them providing DNA sequences: Alberson et al. [2] reported both North and South American haplotypes of Drepanocephalus auritus Kudlai, Kostadinova, Pulis, and Tkach, 2015 (formerly reported as D. spathans Dietz, 1909) in Biomphalaria havanensis L. Pfeiffer, 1839 in catfish aquaculture ponds in Mississippi, most likely due to overlapping feeding ranges of the bird definitive hosts. Furthermore, Georgieva et al. [45] provided the first report of Ec. miyagawai Ishii 1932 in mallard, Anas platyrhynchos L., in New Zealand having previously reported it from the same host, as well as tufted duck, Aythya fuligula L. and P. planorbis snails in Europe [46]. We assume that it is likely that human-caused introductions of waterfowl rather than bird migration led to the introduction of Ec. miyagawai to New Zealand, where it could possibly adapt to a local intermediate snail host. Interestingly, Laidemitt et al. [84] reasoned that in Africa and South America, there might be similar trematode species using related snail and bird hosts, suggesting the historical connection of the continents as the cause. In the northern hemisphere, there could be a similar situation, or at least it could be assumed that some of the sister species (e.g. Ec. revolutum) diversified. The overlap of "European" and "North American" echinostome species was observed only in Iceland; however, there are no data from North Russia to evaluate the species exchange via the Bering Strait or a possible circumpolar distribution of some species, given that the common snail R. balthica was recorded in Siberia [133]. Moreover, more data from more southern regions of the northern hemisphere are required to fully decipher species ranges.

It has also been noted that migratory birds are likely to change their migration patterns in response to climate change [60, 63, 140], leading to migration over larger distances with an increased number of stopovers [60] and longer lengths of stay at stopovers [92]. Shifts in species ranges have also been predicted for some snail species, indicating range contractions rather than expansions on both hemispheres [19, 124]. Such changes of parasite host ranges will require more focused investigations in order to better understand the full extent of parasite distributions.

Therefore, further large-scale sampling of echinostomes from the natural snail host populations in areas where birds, their primary hosts, are abundant are needed. And studies providing molecular evaluation of echinostome adults are required to clarify species identity which will shed more light on the species diversity and host associations which can be used in evaluation of parasite latitudinal range shifts. Moreover, based on the distribution of at least two species (e.g. Echinoparyphium sp. 2 and $N$. islandicus) extending across both North America and Iceland 
in the present study, it is clear that large-scale studies are essential for assessing geographical distribution of these parasites.

Although in recent years the family Echinostomatidae has received considerable attention, particularly in molecular genetic studies, there is still a need for such studies to gain data for accurate species identification, especially within the species complexes ("revolutum" complex and "trivolvis" complex). This should be achieved by following similar guidelines for "best molecular practice" recommended in trematode systematics [9]. DNA barcode sequencing became an essential resource for trematode identification particularly when working with their larval stages. These can be identified reliably to species or genus level via comparison to accurately identified sequence data available in public DNA databases. When publishing new DNA sequence data, it is important to consider previous studies and follow uniform data presentation and subsequent numbering of unidentified species. This will help to avoid misidentification and misinterpretations in later studies and will increase our understanding of the diversity of trematodes.

\section{Supplementary Materials}

The supplementary of this article is available at https:// www.parasite-journal.org/10.1051/parasite/2021054

Supplementary Table S1: Pairwise comparisons of genetic distances of the highlighted clades (see Fig. 1) between Echinoparyphium spp. based on nad 1 sequences.

Supplementary Table S2: Pairwise comparisons of genetic distances of the highlighted clades (see Fig. 2) between Echinostoma spp. based on nad 1 sequences.

Supplementary Table S3: Pairwise comparisons of genetic distances of the highlighted clades (see Fig. 3) between Neopetasiger spp. based on nad 1 sequences.

Supplementary Table S4: Pairwise comparisons of genetic distances of the highlighted clades (see Fig. 4) between the members of the Echinostomatidae based on $28 S$ sequences.

\section{Conflict of interest}

The authors declare that they have no conflict of interest.

Acknowledgements. The present study was funded by the Czech Grant Agency (project No. 18-18597S), the research fund from the University of Iceland, and by the institutional support of the Institute of Parasitology, BC CAS CR (RVO: 60077344). We are grateful to A. Karvonen (University of Jyväskylä, Finland) and O. Seppälä (University of Innsbruck, Austria) for providing infected snails from Huumonjärvi, Finland, and to D. Larsson (University of Alaska, Fairbanks) for help with sampling and providing lab space in Fairbanks, Alaska. We are also grateful to Libuše Kolářová (Charles University, Czech Republic) for help with sampling in Ireland.

\section{References}

1. Acosta AA, Smit NJ, Silva RJ. 2020. Diversity of helminth parasites of eight siluriform fishes from the Aguapeí River, upper Paraná basin, São Paulo state, Brazil. International Journal for Parasitology: Parasites and Wildlife, 11, 120-128.

2. Alberson NR, Rosser TG, Buddenborg SK, Khoo LH, Loker ES, Richardson TD, Woodyard ET, Wise DJ, Pote LM, Griffin
MJ. 2017. North and South American haplotypes of Drepanocephalus auritus (Digenea: Echinostomatidae) are released from Biomphalaria havanensis (Mollusca: Planorbidae) inhabiting catfish aquaculture ponds in Mississippi, U.S.A. Comparative Parasitology, 84, 87-101.

3. Albrecht C, Wolff C, Glöer P, Wilke T. 2008. Concurrent evolution of ancient sister lakes and sister species: the freshwater gastropod genus Radix in lakes Ohrid and Prespa. Hydrobiologia, 615, 157-167.

4. Albrecht C, Föller K, Clewing C, Hauffe T, Wilke T. 2014. Invaders versus endemics: alien gastropod species in ancient Lake Ohrid. Hydrobiologia, 739, 163-174.

5. Beaver PC. 1937. Experimental studies on Echinostoma revolutum (Froelich), a fluke from birds and mammals. Illinois Biological Monographs, 15, 1-95.

6. Beran L, Horsák M. 2002. Gyraulus parvus (Mollusca: Gastropoda) in the Czech Republic. Acta Societatis Zoologicae Bohemicae, 66, 81-84.

7. Blair D. 1973. Observations and experiments on some larval trematodes of freshwater snails and fish from southern Iceland. Journal of Helminthology, 47, 409-414.

8. Blasco-Costa I, Faltýnková A, Georgieva S, Skírnisson K, Scholz T, Kostadinova A. 2014. Fish pathogens near the Arctic Circle: molecular, morphological and ecological evidence for unexpected diversity of Diplostomum (Digenea: Diplostomidae) in Iceland. International Journal for Parasitology, 44, 703-715.

9. Blasco-Costa I, Cutmore SC, Miller TL, Nolan MJ. 2016. Molecular approaches to trematode systematics: "best practice" and implications for future study. Systematic Parasitology, 93, 295-306.

10. Bondarenko SK, Kontrimavichus VI. 1999. The helminth fauna of Charadriiformes in Alaska: zoogeographical features and origin. Zoologicheskiy Zhurnal, 78, 643-653 (in Russian).

11. Born-Torrijos A, Paterson RA, van Beest GS, Vyhlídalová T, Henriksen EH, Knudsen R, Kristoffersen R, Amundsen PA, Soldánová M. 2021. Cercarial behaviour alters the consumers functional response of three-spined sticklebacks. Journal of Animal Ecology, 90, 978-988.

12. Boulet M, Potvin C, Shaffer F, Breault A. 2005. Conservation genetics of the threatened horned grebe (Podiceps auritus L.) population of the Magdalen Islands, Québec. Conservation Genetics, 6, 539-550.

13. Brglez J, Valtonen TE. 1987. Trematodes in some anseriform birds from the Island of Hailuoto in the Bay of Bothnia (Finland). Veterinarski Arhiv, 57, 177-182.

14. Brinkmann A. 1956. Trematoda. The Zoology of Iceland, 2 (11). Copenhagen and Reykjavík: Ejnar Munksgaard.

15. Burch JB. 1982. Freshwater snails (Mollusca: Gastropoda) of North America. U.S. Environmental Protection Agency: Cincinati.

16. Canaris AG, Kinsella JM. 2000. Helminth parasites in six species of shorebirds (Charadrii) from Bristol Bay, Alaska, U.S. A. Comparative Parasitology, 67, 250-252.

17. Canaris AG, Kinsella JM. 2007. Helminth communities of three sympatric species of shorebirds (Charadrii) from four summer seasons at Bristol Bay, Alaska. Journal of Parasitology, 93, 485-490.

18. Carlson CJ, Burgio KR, Dougherty ER, Phillips AJ, Bueno VM, Clements CF, Castaldo G, Dallas TA, Cizauskas CA, Cumming GS, Doña J, Harris NC, Jovani R, Mironov S, Muellerklein OC, Proctor HC, Getz WM. 2017. Parasite biodiversity faces extinction and redistribution in a changing climate. Science Advances, 3, e1602422.

19. Cordellier M, Pfenninger A, Streit B, Pfenninger M. 2012. Assessing the effects of climate change on the distribution of 
pulmonate freshwater snail biodiversity. Marine Biology, 159, 2519-2531.

20. Correa AC, Escobar JS, Durand P, Renaud F, David P, Jarne P, Pointier JP, Hurtrez-Boussès S. 2010. Bridging gaps in the molecular phylogeny of the Lymnaeidae (Gastropoda: Pulmonata), vectors of Fascioliasis. BMC Evolutionary Biology, 10, 1-12.

21. Cort WW. 1914. Some North American larval trematodes. Illinois Biological Monographs, 1, 1-71.

22. Cramp S, Simmons KEL. 1983. Handbook of the birds of Europe, the Middle East and North Africa. The Birds of the Western Palearctic (Vol. 3). Waders to Gulls. Oxford University Press: Oxford.

23. Darriba D, Taboada GL, Doallo R, Posada D. 2012. jModelTest 2: more models, new heuristics and parallel computing. Nature Methods, 9, 772 .

24. Detwiler JT, Bos DH, Minchella DJ. 2010. Revealing the secret lives of cryptic species: Examining the phylogenetic relationships of echinostome parasites in North America. Molecular Phylogenetics and Evolution, 55, 611-620.

25. Detwiler JT, Zajac AM, Minchella DJ, Belden LK. 2012. Revealing cryptic parasite diversity in a definitive host: Echinostomes in muskrats. Journal of Parasitology, 98, 1148-1155.

26. Dillon RT, Wethington AR, Rhett JM, Smith TP. 2002. Populations of the European freshwater pulmonate Physa acuta are not reproductively isolated from American Physa heterostropha or Physa integra. Invertebrate Biology, 121, 226-234.

27. Dreyfuss G, Vignoles P, Abrous M, Rondelaud D. 2002. Unusual snail species involved in the transmission of Fasciola hepatica in watercress beds in central France. Parasite, 9, 113-120.

28. Ebbs ET, Loker ES, Brant SV. 2018. Phylogeography and genetics of the globally invasive snail Physa acuta Draparnaud 1805 , and its potential to serve as an intermediate host to larval digenetic trematodes. BMC Evolutionary Biology, 18, 103.

29. Edgar RC. 2004. MUSCLE: multiple sequence alignment with high accuracy and high throughput. Nucleic Acids Research, 32, 1792-1797.

30. Erickson EM, Found-Jackson C, Boyce M. 2017. Habitat associations with counts of declining Western Grebes in Alberta. Canada. Avian Conservation and Ecology, 12, 12.

31. Faltýnková A, Georgieva S, Kostadinova A, Blasco-Costa I, Scholz T, Skírnisson K. 2014. Diplostomum von Nordmann, 1832 (Digenea: Diplostomidae) in the sub-Arctic: descriptions of the larval stages of six species discovered recently in Iceland. Systematic Parasitology, 89, 195-213.

32. Faltýnková A, Georgieva S, Soldánová M, Kostadinova A. 2015. A re-assessment of species diversity within the "revolutum" group of Echinostoma Rudolphi, 1809 (Digenea: Echinostomatidae) in Europe. Systematic Parasitology, 90, 1-25.

33. Faltýnková A, Haas W. 2004. Larval trematodes in freshwater molluscs from Elbe to Danube rivers (South-east Germany): before and today. Parasitology Research, 99, 572-582.

34. Faltýnková A, Našincová V, Kablásková L. 2007. Larval trematodes (Digenea) of the great pond snail, Lymnaea stagnalis (L.), (Gastropoda, Pulmona) in Central Europe: a survey of species and key to their identification. Parasite, 14, 39-51.

35. Faltýnková A, Našincová V, Kablásková L. 2008. Larval trematodes (Digenea) of planorbid snails (Gastropoda: Pulmonata) in Central Europe: a survey of species and key to their identification. Systematic Parasitology, 69, 155-178.

36. Faltýnková A, Pantoja C, Skírnisson K, Kudlai O. 2020. Unexpected diversity in northern Europe: trematodes from salmonid fishes in Iceland with two new species of Crepidostomum Braun, 1900. Parasitology Research, 119, 2439-2462.
37. Faltýnková A, Valtonen ET, Karvonen A. 2008. Spatial and temporal structure of the trematode component community in Valvata macrostoma (Gastropoda, Prosobranchia). Parasitology, $135,1691-1699$.

38. Folmer O, Black M, Hoeh W, Lutz R, Vrijenhoek R. 1994. DNA primers for amplification of mitochondrial cytochrome $c$ oxidase subunit I from diverse metazoan invertebrates. Molecular Marine Biology and Biotechnology, 3, 294-299.

39. Fried B, Toledo R. 2009. The biology of echinostomes. From the molecule to the community. Springer: New York. p. 333.

40. Frolova EN. 1975. Trematode larvae in molluscs in South Karelian lakes. Nauka: Leningrad (in Russian).

41. Galaktionov KV, Dobrovolskiy AA. 2003. The biology and evolution of trematodes. An essay on the biology, morphology, life cycles, transmission and evolution of digenetic trematodes. Kluwer Academic Publishers: Boston, Dordrecht, London.

42. Garey JR, Wolstenholme DR. 1989. Platyhelminth mitochondrial DNA: evidence for early evolutionary origin of a tRNA ser AGN that contains a dihydrouridine arm replacement loop, and of serine-specifying AGA and AGG codons. Journal of Molecular Evolution, 28, 374-387.

43. Ganoe LS, Brown JD, Yabsley MJ, Lovallo MJ, Walter WD. 2020. A review of pathogens, diseases, and contaminants of muskrats (Ondatra zibethicus) in North America. Frontiers in Veterinary Science, 7, 233.

44. García-Moreno J, Harrison IJ, Dudgeon D, Clausnitzer V, Darwall W, Farrell T, Savy C, Tockner K, Tubbs N. 2014. Sustaining freshwater biodiversity in the Anthropocene, in The global water system in the Anthropocene. Bhaduri A, Bogardi J, Leentvaar J, Marx S, Editors. Springer: Cham. p. 247-270.

45. Georgieva S, Blasco-Costa I, Kostadinova A. 2017. Molecular characterisation of four echinostomes (Digenea: Echinostomatidae) from birds in New Zealand, with descriptions of Echinostoma novaezealandense n. sp. and Echinoparyphium poulini $\mathrm{n}$. sp. Systematic Parasitology, 94, 477-497.

46. Georgieva S, Faltýnková A, Brown R, Blasco-Costa I, Soldánová M, Sitko J, Scholz T, Kostadinova A. 2014. Echinostoma "revolutum" (Digenea: Echinostomatidae) species complex revisited: species delimitation based on novel molecular and morphological data gathered in Europe. Parasites \& Vectors, 7, 520.

47. Georgieva S, Kostadinova A, Skírnisson K. 2012. The life-cycle of Petasiger islandicus Kostadinova \& Skírnisson, 2007 (Digenea: Echinostomatidae) elucidated with the aid of molecular data. Systematic Parasitology, 82, 177-183.

48. Georgieva S, Selbach C, Faltýnková A, Soldánová M, Sures B, Skírnisson K, Kostadinova A. 2013. New cryptic species of the "revolutum" group of Echinostoma (Digenea: Echinostomatidae) revealed by molecular and morphological data. Parasites \& Vectors, 6, 64.

49. Ginetsinskaya TA, Dobrovolskiy AA. 1964. On the fauna of larval trematodes of freshwater molluscs of the Volga delta. Trudy Astakhanskogo Zapovednika, 9, 64-104 (in Russian).

50. Glöer P. 2002. Die Süßwassergastropoden Nord-und Mitteleuropas. Bestimmungschlüssel, Lebensweise, Verbreitung. Die Tierwelt Deutschlands, Teil 73. ConchBooks: Hackenheim.

51. Gordy MA, Hanington PC. 2019. A fine-scale phylogenetic assessment of digenean trematodes in central Alberta reveals we have yet to uncover their total diversity. Ecology and Evolution, 9, 3153-3238.

52. Gordy MA, Kish L, Tarrabain M, Hanington PC. 2016. A comprehensive survey of larval digenean trematodes and their snail hosts in central Alberta, Canada. Parasitology Research, 115, 3867-3880. 
53. Grabda-Kazubska B, Kiseliene V. 1989. Chaetotaxy and excretory system of the cercaria of Echinoparyphium recurvatum (Linstow, 1873) (Digenea, Echinostomatidae). Acta Parasitologica Polonica, 34, 325-335.

54. Grabda-Kazubska B, Kiseliene V. 1991. The life-cycle of Echinoparyphium mordwilkoi Skrjabin, 1915 (Trematoda, Echinostomatidae). Acta Parasitologica Polonica, 36, 167-173.

55. Greben OB, Kudlai O, Korol EN, Kornyushin VV, Vasilkovska IB, Kobylinsky VV. 2016. A new record of Chaunocephalus ferox (Digenea, Echinostomatidae) from Ciconia nigra in Ukraine including morphological and molecular data. Vestnik Zoologii, 50, 99-104.

56. Guindon S, Dufayard JF, Lefort V, Anisimova M, Hordijk W, Gascuel O. 2010. New algorithms and methods to estimate maximum-likelihood phylogenies: assessing the performance of PhyML 3.0. Systematic Biology, 59, 307-321.

57. Gustafson KD, Kensinger BJ, Bolek MG, Luttbeg B. 2014. Distinct snail (Physa) morphotypes from different habitats converge in shell shape and size under common garden conditions. Evolutionary Ecology Research, 16, 77-89.

58. Harper WF. 1929. On the structure and life-histories of British fresh-water larval trematodes. Parasitology, 21, 189-219.

59. Hoberg EP, Galbreath KE, Cook JA, Kutz SJ, Polley L. 2012. Northern host parasite assemblages: History and biogeography on the borderlands of episodic Climate and Environmental Transition. Advances in Parasitology, 79, 1-97.

60. Howard C, Stephens PA, Tobias JA, Sheard C, Butchart SHM, Willis SG. 2018. Flight range, fuel load and the impact of climate change on the journeys of migrant birds. Proceedings of the Royal Society: Biological Sciences, 285, 20172329.

61. Huffman JE, Fried B. 2012. The biology of Echinoparyphium (Trematoda, Echinostomatidae). Acta Parasitologica, 57, 199-210.

62. Iskova NI. 1985. Fauna of the Ukraine, Volume 34, Trematoda, Part 4, Echinostomata. Naukova Dumka: Kiev (in Russian).

63. Jenni L, Kéry M. 2003. Timing of autumn bird migration under climate change: Advances in long distance migrants, delays in short-distance migrants. Proceedings of the Royal Society: Biological Sciences, 270, 1467-1471.

64. Jeppesen E, Meerhoff M, Holmgren K, González-Bergonzoni I, Teixeira-de Mello F, Declerck SAJ, De Meester L, Søndergaard M, Lauridsen TL, Bjerring R, Conde-Porcuna JM, Mazzeo N, Iglesias C, Reizenstein M, Malmquist HJ, Liu Z, Balayla D, Lazzaro X. 2010. Impacts of climate warming on lake fish community structure and potential effects on ecosystem function. Hydrobiologia, 646, 73-90.

65. Jóhannesdóttir L, Arnalds Ó, Brink S, Gunnarsson TG. 2014. Identifying important bird habitats in a sub-arctic area undergoing rapid land-use change. Bird Study, 61, 544-552.

66. Jouet D, Skírnisson K, Kolářová L, Ferté H. 2010. Molecular diversity of Trichobilharzia franki in two intermediate hosts (Radix auricularia and Radix peregra): a complex of species. Infection Genetics and Evolution, 10, 1218-1227.

67. Kanev I, Sorensen B, Sterner S, Fried B. 1998. The identification and characteristics of Echinoparyphium rubrum (Trematoda: Echinostomatidae) based on experimental evidence of the life cycle. Acta Parasitologica, 43, 181-188.

68. Karmanova EM. 1971. The life-cycle of Petasiger neocomense (Trematoda, Echinostomatidae). Trudy Gelmintologicheskoy Laboratorii, 21, 31-35 (in Russian).

69. Keeler SP, Huffman JE. 2009. Echinostomes in the second intermediate host, in The Biology of Echinostomes. Toledo R, Fried B, Editors. Springer: New York. p. 61-87.
70. Kennedy MJ. 1986. Synopsis of the digenea of mammals of North America. Alberta Agriculture, Animal Health Division, Queen's Printer: Edmonton, Canada.

71. Khan D. 1960. Studies on larval trematodes infecting freshwater snails in London (U.K.) and some adjoining areas. Part I. Echinostome cercariae. Journal of Helminthology, 34, 277-304.

72. Kiseliene V, Grabda-Kazubska B, Moné H. 1997. On morphology and chaetotaxy of Cercaria abyssicola Wesenberg-Lund, 1934 (Digenea, Echinostomatidae). Acta Parasitologica, 42, 7-11.

73. Kostadinova A. 2005. Family Echinostomatidae Looss, 1899, in: Keys to the Trematoda, vol 2, Jones A, Bray RA, Gibson DI, Editors. CAB International and the Natural History Museum: Wallingford - London. p. 9-64.

74. Kostadinova A, Chipev N. 1992. Experimental data on the lifecycle of Petasiger grandivesicularis Ishii, 1935 (Trematoda: Echinostomatidae). Systematic Parasitology, 23, 55-65.

75. Kostadinova A, Gibson DI. 2000. The systematics of the echinostomes, in Echinostomes as experimental models for biological research. Fried B, Graczyk TK, Editors. Kluwer Academic Publishers: Netherlands. p. 31-57.

76. Kostadinova A, Herniou EA, Barrett J, Littlewood DTJ. 2003. Phylogenetic relationships of Echinostoma Rudolphi, 1809 (Digenea: Echinostomatidae) and related genera re-assessed via DNA and morphological analyses. Systematic Parasitology, 54, 159-176.

77. Kostadinova A, Skírnisson K. 2007. Petasiger islandicus n. sp. (Digenea: Echinostomatidae) in the horned grebe Podiceps auritus (L.) (Aves: Podicipedidae) from Iceland. Systematic Parasitology, 68, 217-223.

78. Kudlai O, Pantoja C, O’Dwyer K, Jouet D, Skírnisson K, Faltýnková A. 2021. Diversity of Plagiorchis (Trematoda: Digenea) in high latitudes: Species composition and snail host spectrum revealed by integrative taxonomy. Journal of Zoological Systematics and Evolutionary Research 59, 937-962.

79. Kudlai O, Tkach VV, Pulis EE, Kostadinova A. 2015. Redescription and phylogenetic relationships of Euparyphium capitaneum Dietz, 1909, the type-species of Euparyphium Dietz, 1909 (Digenea: Echinostomatidae). Systematic Parasitology, 90, 53-65.

80. Kumar S, Stecher G, Li M, Knyaz C, Tamura K. 2018. MEGA $\mathrm{X}$ : Molecular Evolutionary Genetics Analysis across computing platforms. Molecular Biology and Evolution, 35, 1547-1549.

81. Kuris AM, Hechinger R, Shaw JC, Whitney KL, AguirreMacedo L, Boch CA, Dobson AP, Dunham EJ, Fredensborg BL, Huspeni TC, Lorda J, Mababa L, Mancini FT, Mora AB, Pickering M, Talhouk ND, Torchin ME, Lafferty KD. 2008. Ecosystem energetic implications of parasite and free-living biomass in three estuaries. Nature, 454, 515-518.

82. Lack PC. 1986. The atlas of wintering birds in Britain and Ireland. T. \& A. D. Poyser: London.

83. Lafferty KD, Sammond DT, Kuris AM. 1994. Analysis of larval trematode communities. Ecology, 75, 2275-2285.

84. Laidemitt MR, Brant SV, Mutuku MW, Mkoji GM, Loker ES. 2019. The diverse echinostomes from East Africa: With a focus on species that use Biomphalaria and Bulinus as intermediate hosts. Acta Tropica, 193, 38-49.

85. Lawton SP, Lim RM, Dukes JP, Kett SM, Cook RT, Walker AJ, Kirk RS. 2015. Unravelling the riddle of Radix: DNA barcoding for species identification of freshwater snail intermediate hosts of zoonotic digeneans and estimating their inter-population evolutionary relationships. Infection, Genetics and Evolution, $35,63-74$.

86. van Leeuwen CHA, Huig N, van der Velde G, van Alen TA, Wagemaker CAM, Sherman CDH, Klaassen M, Figuerola J. 
2013. How did this snail get there? Several dispersal vectors inferred for an aquatic invasive species. Freshwater Biology, 58, $88-99$.

87. Lim HK, Heynemann D. 1972. Intramolluscan inter-trematode antagonism: a review of factors influencing the host-parasite system and its possible role in biological control. Advances in Parasitology, 10, 191-268.

88. Littlewood DT, Curini-Galletti M, Herniou EA. 2000. The interrelationships of Proseriata (Platyhelminthes: Seriata) tested with molecules and morphology. Molecular Phylogenetics and Evolution, 16, 449-466.

89. Littlewood DT, Rohde K, Clough KA. 1997. Parasite speciation within or between host species? - Phylogenetic evidence from site-specific polystome monogeneans. International Journal for Parasitology, 27, 1289-1297.

90. Lorencová E, Beran L, Horsáková V, Horsák M. 2015. Invasion of freshwater molluscs in the Czech Republic: time course and environmental predictors. Malacologia, 59, 105-120.

91. Lydeard C, Campbell D, Golz M. 2016. Physa acuta Draparnaud, 1805 should be treated as a native of North America, not Europe. Malacologia, 59, 347-350.

92. Masero JA, Santiago-Quesada F, Sánchez-Guzmán JM, Villegas A, Abad-Gómez JM, Lopes RJ, Encarnação V, Corbacho C, Morán R. 2011. Long lengths of stay, large numbers, and trends of the Black-tailed Godwit Limosa limosa in rice fields during spring migration. Bird Conservation International, 21, 12-24.

93. McCarthy AM. 1990. Speciation of echinostomes: evidence for the existence of two sympatric sibling species in the complex Echinoparyphium recurvatum (von Linstow, 1873) (Digenea: Echinostomatidae). Parasitology, 101, 35-42.

94. Meier-Brook C. 1983. Taxonomic studies on Gyraulus (Gastropoda: Planorbidae). Malacologia, 24, 1-113.

95. Miquel J, Martellet MR, Acosta L, Toledo R, Pétavy AF. 2018. Reinvestigation of the sperm ultrastructure of Hypoderaeum conoideum (Digenea: Echinostomatidae). Parasitology Research, 117, 3725-3732.

96. Mohanta UK, Watanabe T, Ohari Y, Itagaki T. 2019. Characterization of Echinostoma revolutum and Echinostoma robustum from ducks in Bangladesh based on morphology, nuclear ribosomal ITS2 and mitochondrial nad1 sequences. Parasitology International, 69, 1-7.

97. Morgan JAT, Blair D. 1998. Relative merits of nuclear ribosomal internal transcribed spacers and mitochondrial CO1 and ND1 genes for distinguishing among Echinostoma species (Trematoda). Parasitology, 116, 289-297.

98. Našincová V. 1986. Contribution to the distribution of and the life history of Echinostoma revolutum (Trematoda) in central Europe. Věstník Československé společnosti zoologické, 50, 70-80.

99. Našincová V. 1992. Trematode developmental stages in Czech aquatic snails and life-cycles of selected species of the family Omphalometridae and Echinostomatidae. PhD Thesis, České Budějovice: Institute of Parasitology, Czechoslovak Academy of Sciences, $268 \mathrm{pp}$.

100. Nezvalová J. 1970. Contribution to the knowledge of cercariae of south Moravia. Spisy Př́rodovědecké Fakulty, Universita J.E. Purkyně v Brně. Purkyně v Brně, 515, 217-252 (in Czech).

101. Niewiadomska K, Valtonen ET, Siddall R. 1997. Cercariae from Lymnaea stagnalis in lake Kuuhankavesi (central Finland). Acta Parasitologica, 42, 132-137.

102. Nolan JR, Bergthorsson U, Adema CM. 2014. Physella acuta: atypical mitochondrial gene order among panpulmonates (Gastropoda). Journal of Molluscan Studies, 80, 388-399.
103. Odening K. 1962. Bemerkungen zum Exkretionssystem dreier echinostomer Cercarien sowie zur Identität der Gattungen Neoacanthoparyphium Yamaguti und Allopetasiger Yamaguti (Trematoda: Echinostomatidae). Zeitschrift für Parasitenkunde, 21, 521-534.

104. Odening K. 1965. Eine echinostome Cercarie mit 29 Kragenstacheln aus Gewässern bei Berlin und die Entwicklung ihres Exkretionssystems. Monatsberichte der Deutschen Akademie der Wissenschaften zu Berlin, 7, 818-822.

105. Ohama T, Osawa S, Watanabe K, Jukes TH. 1990. Evolution of the mitochondrial genetic code IV. AAA as an asparagine codon in some animal mitochondria. Journal of Molecular Evolution, 30, 329-332.

106. Olson PD, Cribb TH, Tkach VV, Bray RA, Littlewood TD. 2003. Phylogeny and classification of the Digenea (Platyhelminthes: Trematoda). International Journal for Parasitology, 33, 733-755.

107. Pfenninger M, Cordellier M, Streit B. 2006. Comparing the efficacy of morphologic and DNA-based taxonomy in the freshwater gastropod genus Radix (Basommatophora, Pulmonata). BMC Evolutionary Biology, 6, 1-14.

108. Pinto HA, Griffin MJ, Quiniou SM, Ware C, Melo AL. 2016. Biomphalaria straminea (Mollusca: Planorbidae) as an intermediate host of Drepanocephalus spp. (Trematoda: Echinostomatidae) in Brazil: a morphological and molecular study. Parasitology Research, 115, 51-62.

109. Pulis EE, Tkach VV, Newman RA. 2011. Helminth parasites of the wood frog, Lithobates sylvaticus, in prairie pothole wetlands of the Northern Great Plains. Wetlands, 31, 675-685.

110. Rambaut A. 2012. Institute of Evolutionary Biology. Molecular evolution, phylogenetics and epidemiology, Vol. FigTree v1 (p. 4). University of Edinburgh.

111. Rašín K. 1933. Echinoparyphium recurvatum (Linstow, 1873) and its development. Biologické spisy Vysoké školy zvěrolékařské, Brno, 12, 1-104 (in Czech).

112. Reid AJ, Carlson AK, Creed IF, Eliason EJ, Gell PA, Johnson PTJ, Kidd KA, MacCormack TJ, Olden JD, Ormerod SJ, Smol JP, Taylor WW, Tockner K, Vermaire JC, Dudgeon D, Cooke SJ. 2019. Emerging threats and persistent conservation challenges for freshwater biodiversity. Biological Reviews, 94, 849-873.

113. Ronquist F, Teslenko M, Van Der Mark P, Ayres DL, Darling A, Höhna S, Huelsenbeck JP. 2012. MrBayes 3.2: efficient Bayesian phylogenetic inference and model choice across a large model space. Systematic Biology, 61, 539-542.

114. Saadi AJ, Davison A, Wade CM. 2020. Molecular phylogeny of freshwater snails and limpets (Panpulmonata: Hygrophila). Zoological Journal of the Linnean Society, 190, 528-531.

115. Saito T, Hirano T, Prozorova L, Do VT, Sulikowska-Drozd A, Sitnikova T, Surenkhorloo P, Yamazaki D, Morii Y, Kameda Y, Fukuda H, Chiba S. 2018. Phylogeography of freshwater planorbid snails reveals diversification patterns in Eurasian continental islands. BMC Evolutionary Biology, 18, 1-13.

116. Schniebs K, Glöer P, Vinarski M, Hundsdoerfer A. 2011. Intraspecific mophological and genetic variability in Radix balthica (Linnaeus, 1758) (Gastropoda: Basommatophora: Lymnaeidae) with morphological comparison to other European Radix species. Journal of Conchology, 40, 657-678.

117. Selbach C, Soldánová M, Feld CK, Kostadinova A, Sures B. 2020. Hidden parasite diversity in a European freshwater system. Scientific Reports, 10, 1-14.

118. Selbach C, Soldánová M, Georgieva S, Kostadinova A, Kalbe M, Sures B. 2014. Morphological and molecular data for larval 
stages of four species of Petasiger Dietz, 1909 (Digenea: Echinostomatidae) with an updated key to the known cercariae from the Palaearctic. Systematic Parasitology, 89, 153-166.

119. Sitko J, Faltýnková A, Scholz T. 2006. Checklist of the trematodes (Digenea) of birds of the Czech and Slovak Republics. Academia: Prague.

120. Skírnisson K, Kolářová L. 2008. Diversity of bird schistosomes in anseriform birds in Iceland based on egg measurements and egg morphology. Parasitology Research, 103, 43-50.

121. Snyder SD, Tkach VV. 2001. Phylogenetic and biogeographical relationships among some holarctic frog lung flukes (Digenea: Haematoloechidae). Journal of Parasitology, 87, 1433-1440.

122. Soldánová M, Georgieva S, Roháčová J, Knudsen R, Kuhn JA, Henriksen EH, Amundsen PA. 2017. Molecular analyses reveal high species diversity of trematodes in a sub-Arctic lake. International Journal for Parasitology, 47, 327-345.

123. Stanevičiūtė G, Stunžènas V, Petkevičiūtė R. 2015. Phylogenetic relationships of some species of the family Echinostomatidae Odner, 1910 (Trematoda), inferred from nuclear rDNA sequences and karyological analysis. Comparative Cytogenetics, 9, 257-270.

124. Stensgaard A-S, Utzinger J, Vounatsou P, Hürlimann E, Schur N, Saarnak CFL, Simoonga C, Mubita P, Kabatereine NB, Tchuenté L-AT, Rahbek C, Kristensen TK. 2013. Large-scale determinants of intestinal schistosomiasis and intermediate host snail distribution across Africa: Does climate matter? Acta Tropica, 128, 378-390.

125. Summers RW, Boland H, Colhoun K, Elkins N, Etheridge B, Foster S, Fox JW, Mackie K, Quinn LR, Swann RL. 2014. Contrasting trans-Atlantic migratory routes of Nearctic purple sandpipers Calidris maritima associated with low pressure systems in spring and winter. Ardea, 102, 139-152.

126. Tkach VV, Kudlai O, Kostadinova A. 2016. Molecular phylogeny and systematics of the Echinostomatoidea Looss, 1899 (Platyhelminthes: Digenea). International Journal for Parasitology, 46, 171-185.

127. Tkach V, Pawlowski J, Mariaux J. 2000. Phylogenetic analysis of the suborder Plagiorchiata (Platyhelminthes, Digenea) based on partial lsrDNA sequences. International Journal for Parasitology, 30, 83-93.

128. Tkach V, Pawlowski J, Mariaux J, Swiderski Z. 2001. Molecular phylogeny of the suborder Plagiorchiata and its position in the system of Digenea, in Interrelationships of platyhelminthes. Littlewood DTJ, Bray RA, Editors. Taylor \& Francis: London. p. 186-193.

129. Tkach VV, Schroeder JA, Greiman SE, Vaughan JA. 2012. New genetic lineages, host associations and circulation pathways of Neorickettsia endosymbionts of digeneans. Acta Parasitologica, 57, 285-292.

130. Toledo R, Esteban JG. 2016. An update on human echinostomiasis. Transactions of the Royal Society of Tropical Medicine and Hygiene, 110, 37-45.

131. Toledo R, Muñoz-Antolí C, Pérez M, Esteban J. 1998. Larval trematode infections in freshwater gastropods from the Albufera Natural Park in Spain. Journal of Helminthology, 72, 79-82.

132. Väyrynen T, Siddall R, Valtonen ET, Taskinen J. 2000. Patterns of trematode parasitism in lymnaeid snails from northern and central Finland. Annales Zoologici Fennici, 37, 189-199.

133. Vinarski MV, Bolotov IN, Aksenova OV, Babushkin ES, Bespalaya V, Makhrov AA, Nekhaev IO, Vikhrev I. 2021. Freshwater Mollusca of the circumpolar Arctic: a review on their taxonomy, diversity and biogeography. Hydrobiologia, 848, 2891-2918.

134. deWaard JR, Levesque-Beaudin V, deWaard SL, Ivanova NV, McKeown JTA, Miskie R, Naik S, Perez KHJ, Ratnasingham S, Sobel CN, Sones JE, Steinke C, Telfer AC, Young AD, Young MR, Zakharov EV, Hebert PDN. 2019. Expedited assessment of terrestrial arthropod diversity by coupling Malaise traps with DNA barcoding. Genome, 62, 85-95.

135. Welter-Schultes F. 2012. European non-marine molluscs, a guide for species identification. Planet Poster Editions: Göttingen.

136. Werle E, Schneider C, Volker M, Fiehn W. 1994. Convenient single-step, one tube purification of PCR products for direct sequencing. Nucleic Acids Research, 22, 4354-4355.

137. Wesenberg-Lund C. 1934. Contributions to the development of the Trematoda Digenea. Part II. The biology of the freshwater cercariae in Danish freshwaters. Mémoirs de l'Académie Royale des Sciences et des Lettres de Danemark, Copenhague, 9, 1-223.

138. Wikgren BJ. 1956. Studies on Finnish larval flukes with a list of known Finnish adult flukes (Trematoda: Malacocotylea). Acta Zoologica Fennica, 91, 1-106.

139. Wrona F, Reist JD. 2013. Freshwater ecosystems, in Arctic Biodiversity Assessment. Status and Trends in Arctic Biodiversity. Meltofte H, Editor. Conservation of Arctic Flora and Fauna: Akureyri. p. 335-377.

140. Zaifman J, Shan D, Ay A, Jimenez AG. 2017. Shifts in bird migration timing in North American long-distance and shortdistance migrants are associated with climate change. International Journal of Zoology, 2017, 1-9.

141. Zdun VI. 1961. Larval trematodes in freshwater molluscs of the Ukraine. Ukrainian Academy of Sciences Press: Kiev (in Ukrainian).

Cite this article as: Pantoja C, Faltýnková A, O’Dwyer K, Jouet D, Skírnisson K \& Kudlai O. 2021. Diversity of echinostomes (Digenea: Echinostomatidae) in their snail hosts at high latitudes. Parasite 28, 59. 
An international open-access, peer-reviewed, online journal publishing high quality papers on all aspects of human and animal parasitology

Reviews, articles and short notes may be submitted. Fields include, but are not limited to: general, medical and veterinary parasitology; morphology, including ultrastructure; parasite systematics, including entomology, acarology, helminthology and protistology, and molecular analyses; molecular biology and biochemistry; immunology of parasitic diseases; host-parasite relationships; ecology and life history of parasites; epidemiology; therapeutics; new diagnostic tools.

All papers in Parasite are published in English. Manuscripts should have a broad interest and must not have been published or submitted elsewhere. No limit is imposed on the length of manuscripts.

Parasite (open-access) continues Parasite (print and online editions, 1994-2012) and Annales de Parasitologie Humaine et Comparée (1923-1993) and is the official journal of the Société Française de Parasitologie. 